Norbert SzCZęch*

\title{
UDOSTĘPNIANIE INFORMACJI PUBLICZNEJ PRZEZ PARTIE POLITYCZNE
}

\section{Wstęp}

Niniejszy artykuł dotyczy zakresu obowiązku udostępniania informacji publicznej w odniesieniu do partii politycznych, na tle orzecznictwa sądów administracyjnych oraz rozważań doktrynalnych. Jest to tematyka nieposiadająca szerokiej literatury. Również samo orzecznictwo w tym zakresie nie jest zbyt obszerne. Zostało to zauważone i podniesione jako argument przez jedną z partii politycznych w swojej odpowiedzi na skargę, co zaowocowało ostatecznie wymierzeniu jej przez sąd grzywny w niskim wymiarze ${ }^{1}$.

Niniejsze opracowanie ma zatem posłużyć przedstawieniu węzłowych problemów, jakie pojawiają się w praktyce, jak również, rozbieżnych niekiedy, odpowiedzi i rozwiązań formułowanych przez sądy administracyjne, przedstawionych na tle poglądów formułowanych w doktrynie prawa. Punkt pierwszy artykułu dotyczy zagadnień ogólnych jawności i udostępniania informacji, z uwzględnieniem regulacji konstytucyjnych i ustawowych. Następne części opracowania poświęcone zostały omówieniu konkretnych zagadnień problemowych wynikających z orzecznictwa: zakres elementu publicznego w działalności partii politycznych, udostęp-

* Dr, Państwowa Wyższa Szkoła Zawodowa w Tarnowie; e-mail: norbert.szczech@ wp.pl.

1 Wyrok Wojewódzkiego Sądu Administracyjnego w Warszawie z 18 listopada 2015 r., II SAB/Wa 714/15. 
nianie informacji o finansach partyjnych, element wewnętrzny w działalności partii politycznych, odmowa udostępnienia informacji.

\section{Zasada jawności a udostępnianie informacji publicznej}

Obowiązek udostępniania informacji publicznej jest korelatem prawa do informacji ${ }^{2}$, które z kolei stanowi podstawowy element zasady jawności ${ }^{3}$. Zasada ta jest uważana za jedną $\mathrm{z}$ fundamentalnych wartości państwa prawa i warunek efektywnego funkcjonowania systemu demokratycznego ${ }^{4}$. Zapewnienie możliwości pozyskiwania informacji o działalności organów władzy publicznej, a także osób pełniących określone funkcje publiczne wpływa bezpośrednio na poziom demokratyzmu $\mathrm{w}$ państwie ${ }^{5} \mathrm{i}$ jest niezwykle istotnym elementem tej działalności ${ }^{6}$. Zasada ta jest uznana $\mathrm{w}$ Europie Zachodniej od lat 60-tych XX w. jako rezultat podania $\mathrm{w}$ wątpliwość tradycyjnego modelu administracji, którego jedną $\mathrm{z}$ istotnych cech był zwyczaj nieinformowania tych, którzy administrowaniu i rządzeniu byli poddani, zachowywanięa informacji przez władzę, w przekonaniu, że wzmaga to pewność i dominację․ Jawność jest zatem próbą zniwelowania dyskrecjonalności, arbitralności administracji ${ }^{8}$. Stymuluje ona postawy obywatelskie, jest środkiem, który łagodzi i niweluje niepokoje społeczne ${ }^{9}$.

${ }^{2}$ E. Olejniczak-Szałkowska, Zasada jawności administracyjnej, [w:] M. Stahl (red.), Prawo administracyjne. Pojęcia, instytucje, zasady w teorii i orzecznictwie, Warszawa 2013, s. 153-154.

${ }^{3} \mathrm{~K}$. Tomaszewska, Realizacja jawności orzeczeń sadowych w trybie dostępu do informacji publicznej jako element społecznej kontroli, "Przegląd Prawa Konstytucyjnego" 2015, nr 3, s. 18.

4 T.R. Aleksandrowicz, Komentarz do ustawy o dostępie do informacji publicznej, Warszawa 2002, s. 7-10.

5 W. Skrzydło, Konstytucja RP. Komentarz, Kraków 1998, s. 58 i n.

${ }^{6}$ B. Dolnicki, R. Cybulska, Realizacja zasady jawności i dostępu do informacji publicznej w samorządzie terytorialnym, [w:] J. Kosiński, K. Krak (red.), Korupcja i antykorupcja-wybrane zagadnienia, Szczytno 2011, s. 6.

7 T. Górzyńska, Geneza i rozwój prawa do informacji, [w:] A. Dragoń, A. Lityński, G. Sibiga (red.), Wspótczesne problemy samorzadu terytorialnego - dostęp do informacji publicznej, Tychy 2004, s 127.

${ }^{8}$ E. Koniuszewska, Środki ograniczające nadużycia władzy w jednostkach samorzadu terytorialnego w ustrojowym prawie administracyjnym, Warszawa 2009, s. 125.

9 A. Piskorz-Ryń, Dostęp do informacji publicznej - zasady konstrukcyjne ustawy , "Kwartalnik Prawa Publicznego" 2002, nr 4, s. 185. 
W polskim porządku prawnym brak legalnej definicji jawności, natomiast $\mathrm{w}$ doktrynie bywa ona określana jako idea, przeciwieństwo pojęcia tajności, postulowany stan rzeczy, do którego państwo dąży, nie zawsze jednak w pełni go realizuje ${ }^{10}$. Jest to stan względnego braku przeszkód, aby być poinformowanym i móc informować innych, czyli aby móc poszukiwać informacji, domagać się jej, otrzymywać i przekazywać ${ }^{11}$.

Zasada jawności życia publicznego jest rekonstruowana z art. 51, art. 54 oraz przede wszystkim art. 61 Konstytucji $\mathrm{RP}^{12}$. Na podstawie odesłań konstytucyjnych jest ona konkretyzowana $\mathrm{w}$ licznych przepisach ustawowych, dotyczących przede wszystkim form gromadzenia informacji o jednostkach, szczegółowego określania przesłanek ograniczania dostępu do informacji, szczegółowego wyliczania podmiotów zobowiązanych do udzielenia informacji, określenia form udostępniania informacji publicznej oraz ustanawiania przepisów gwarantujących realizację prawa do informacji ${ }^{13}$. Prawo dostępu do informacji stanowi bowiem element kontroli władzy publicznej przez obywateli oraz ich uczestnictwa w sprawowaniu tej władzy ${ }^{14}$. Z orzecznictwa Trybunału Konstytucyjnego oraz sądów administracyjnych i powszechnych wynika, że zasada jawności jest zasadą konstytucyjna, atrybutem demokratycznego państwa prawnego, jednak w judykaturze nie przeprowadzono szczegółowej analizy tej zasady, ograniczając się zazwyczaj do stwierdzenia, że rozwinięciem konstytucyjnej zasady jawności są przede wszystkim uprawnienia obywateli do uzyskiwania informacji ${ }^{15}$.

Konstytucja RP odnosi się do prawa do informacji w czterech artykułach: art. 51 określającym zasady pozyskiwania, gromadzenia i udostępniania informacji o osobach; art. 54 zapewniającym wolność pozyskiwania i rozpowszechniania informacji; art. 61 dotyczącym bezpośrednio udostępniania informacji publicznej oraz art. 74 gwarantującym prawo do-

10 Taż, Jawność działania administracji publicznej, [w:] H. Machińska (red.), Prawo do dobrej administracji, Warszawa 2003, s. 488.

${ }_{11}$ T. Górzyńska, Prawo do informacji i zasada jawności administracyjnej. Orzecznictwo Sąu Najwyższego oraz Trybunału Konstytucyjnego, Kraków 1999, s. 19-20.

${ }^{12}$ Konstytucja Rzeczypospolitej Polskiej z dnia 2 kwietnia 1997 r. (Dz. U. Nr 78, poz. 483 z późn. zm.).

${ }_{13}$ P.A. Tusiński, Zasady ogólne materialnego prawa administracyjnego, [w:] M. Zdyb, J. Stelmasiak (red.), Prawo administracyjne, Warszawa 2016, s. 185.

${ }^{14}$ G. Sibiga (red.), Główne problemy prawa do informacji w świetle prawa i standardów międzynarodowych, europejskich i wybranych państw Unii Europejskiej, Warszawa 2013, s. 31.

${ }^{15}$ K. Tarnacka, Prawo do informacji w polskim prawie konstytucyjnym, Warszawa 2009, s 22 . 
stępu do informacji o środowisku. Z tego względu w nauce można spotkać się z poglądem o wielości praw do informacji ${ }^{16}$, jednakże większość przedstawicieli doktryny skłania się ku uznaniu szerokiej konstytucyjnej koncepcji jednego prawa do informacji, które jest rozproszone w kilku przepisach $^{17}$.

Prawo do uzyskiwania informacji o działalności organów władzy publicznej oraz osób pełniących funkcje publiczne zawarte zostało $\mathrm{w}$ art. 61 ust. 1 Konstytucji w jej rozdziale II zatytułowanym „Wolności, prawa i obowiązki człowieka i obywatela". Prawo to należy zatem do wolności i praw politycznych. Obejmuje ono również uzyskiwanie informacji o działalności organów samorządu gospodarczego i zawodowego, a także innych osób oraz jednostek organizacyjnych w zakresie, w jakim wykonują one zadania władzy publicznej i gospodarują mieniem komunalnym lub majątkiem Skarbu Państwa. Stosownie do art. 61 ust. 2 Konstytucji, prawo do uzyskiwania informacji obejmuje dostęp do dokumentów oraz wstęp na posiedzenia kolegialnych organów władzy publicznej pochodzących z powszechnych wyborów, z możliwością rejestracji dźwięku lub obrazu. Zgodnie z art. 61 ust. 4 Konstytucji tryb udzielania informacji, o których mowa w ust. 1 i 2, określają ustawy, a w odniesieniu do Sejmu i Senatu ich regulaminy.

Gwarancje konstytucyjne dotyczące prawa dostępu do informacji (art. 61) nie mogą być $\mathrm{w}$ pełni utożsamione $\mathrm{z}$ prawem określonym $\mathrm{w}$ art. 54 , zapewniającym wolność wyrażania poglądów oraz pozyskiwania i rozpowszechniania informacji, bowiem wolność pozyskiwania i rozpowszechnienia informacji jest ujęta szerzej niż $\mathrm{w}$ art. 61 Konstytucji ${ }^{18}$. Konstytucyjne prawo dostępu do informacji publicznej traktowane jest współcześnie jako niezbędna przesłanka istnienia społeczeństwa obywatelskiego, łącząc się z koncepcją tzw. otwartego rządu ${ }^{19}$. Prawo do informacji traktowane jest jako gwarancja otwartości instytucji publicznych,

16 Taż, Prawo do informacji w Polsce, „Państwo i Prawo” 2003, nr 5, s. 75.

17 E. Jarzęcka-Siwik, Jawność warunkiem skutecznego i etycznego działania administracji, „Kontrola Państwowa” 2005, nr 1, s. 114-137.

${ }^{18}$ S. Bułajewski, D. Ossowska-Salamonowicz, Jawność działania organów wykonawczych jednostek samorzadu terytorialnego - wybrane zagadnienia, "Journal of Modern Science" 2016, nr 4, s. 399.

${ }_{19}$ M. Jabłoński, Społeczeństwo obywatelskie a konstytucyjne prawo dostępu do informacji publicznej, [w:] E. Gdulewicz, H. Zięba-Załucka (red.), Dziesięć lat Konstytucji Rzeczypospolitej Polskiej, Rzeszów 2007, s. 89. 
która z kolei stanowi istotny element pełnionych przez nie funkcji służebnych wobec społeczeństwa ${ }^{20}$.

Szczegółowy charakter art. 61 Konstytucji wskazuje, że prawo do informacji było rozważane na tle technik utrwalania i rozpowszechniania informacji spoczywających w gestii samych uprawnionych ${ }^{21}$, jednak kwestia przetwarzania informacji po stronie podmiotów władzy publicznej, sposób realizacji „dostępu” czy wreszcie pojęcie „dokumentu” pozostawiono swobodzie ustawodawcy ${ }^{22}$.

Aktem prawnym rangi ustawowej, który dotyczy omawianej problematyki, jest ustawa o dostępie do informacji publicznej z $2001 \mathrm{r}^{23}$ Zgodnie z jej art. 1 ust. 1 każda informacja o sprawach publicznych stanowi informację publiczną w rozumieniu ustawy i podlega udostępnieniu i ponownemu wykorzystywaniu na zasadach i w trybie określonych w tym akcie prawnym.

W świetle tego przepisu podzielić można pogląd, że zdefiniowanie przez ustawodawcę tego, czym jest informacja publiczna, jak również określenie procesu jej udostępniania, jest bardzo lakoniczne ${ }^{24}$. Ustawa nie daje jednoznacznej odpowiedzi na pytanie, jaką kategorię posiadanych przez urzędy informacji możemy traktować jako informacje publiczną ${ }^{25}$. Co więcej, w doktrynie napotkać można pogląd, iż określenie informacji publicznej z art. 1 ust. 1 UDIP obarczone jest błędem ignotum per ignotum ${ }^{26}$. Jednakże inni przedstawiciele nauki prawa zauważaja, że ustawodawca przyjął, poprzez objęcie powyższą definicją szerokiej sfery informacji

${ }^{20}$ J. Czerw, Prawo do informacji publicznej w praktyce działania urzędów administracji samorządowej, „Rocznik Administracji Publicznej” 2016, nr 2, s. 8.

${ }_{21}$ B. Banaszak, Konstytucja Rzeczypospolitej Polskiej. Komentarz, Warszawa 2009, s. 316317.

${ }^{22}$ M. Bernaczyk, Wybrane problemy udostępniania informacji publicznych w BIP w świetle orzecznictwa sąów administracyjnych oraz propozycje ich przezwyciężania, informacjapubliczna.org.pl [dostęp: 11.03.2017 r.].

${ }_{23}$ Ustawa z dnia 6 września 2001 r. o dostępie do informacji publicznej (tekst jedn. Dz. U. z 2015 r. poz. 2058 z późn. zm.), (dalej: UDIP).

${ }^{24}$ M. Jaśkowska, Dostęp do informacji publicznych w świetle orzecznictwa Naczelnego Sadu Administracyjnego, Toruń 2002, s. 22-23.

${ }^{25}$ A. Jabłońska, Udostępnienie informacji publicznej jako podstawowe prawo społeczeństwa informacyjnego, [w:] A. Lusińska, A. Kalinowska-Żeleźnik (red.), Dostęp do informacji publicznej. Wybrane aspekty teorii i praktyki, Gdańsk 2014, s. 82.

${ }^{26}$ M. Bąkiewicz, Prawo do informacji w jednostkach samorzadu terytorialnego, [w:] T. Gardocka (red.), Obywatelskie prawo do informacji, Warszawa 2008, s. 92. 
i faktów, iż jawność informacji ma charakter generalny ${ }^{27}$. Jest to zatem traktowane jako celowy zabieg racjonalnego ustawodawcy, który przy zastosowaniu zamkniętej i wąskiej definicji zdecydowanie ograniczyłby zakres podmiotowy tej regulacji, skłaniając ponadto część zobowiązanych nią podmiotów do przyjmowania różnych interpretacji wskazanych pojęć, w rezultacie czego mogłyby one przyjąć błędne wyobrażenie o tym, że są zwolnione z obowiązku informowania ${ }^{28}$. Przyjęta przez ustawodawcę $\mathrm{w}$ art. 1 UDIP kategoria traktowana jest jako najszersza, w odróżnieniu od pojęcia "dokument" z art. 61 Konstytucji oraz "dokument urzędowy" $\mathrm{z}$ art. 6 ust. 2 UDIP29.

Ustawowy zwrot "sprawy publiczne” doczekał się doktrynalnego dopracowania w postaci poglądu, że za sprawę publiczną należy uznać wszystkie działania lub zaniechania organów władzy publicznej, osób (piastunów) tworzących skład osobowy tych organów, jak również osób uczestniczących w wykonywaniu zadań władzy publicznej, w tym ich kompetencji, oraz $\mathrm{w}$ gospodarowaniu majątkiem publicznym $\mathrm{w}$ ramach działań o charakterze organizacyjnym, materialnym i proceduralnym w zakresie im powierzonym ${ }^{30}$.

Jak zauważono, pojęcia „sprawy publicznej” oraz „informacji publicznej" są ze sobą powiązane, ale nie są tożsame ${ }^{31}$. Przesłanką kwalifikującą konkretną informację do kategorii informacji publicznej jest bowiem spełnienie przez nią kryterium przedmiotowego. $\mathrm{O}$ tej kwalifikacji lub jej braku przesądzać będzie zatem treść i charakter konkretnej informacji, a nie podmiot, który znajduje się w jej posiadaniu. Oznacza to więc, że celem żądania może być uzyskanie informacji dotyczącej zaistniałych faktów, czyli takich, które wystąpiły i miały lub mają wpływ na sferę publiczną ${ }^{32}$.

27 P. Sitniewski, Bezpłatność czy bezkosztowość udostępniania informacji publicznej?, [w:] E. Ura (red.), Sprawność działania administracji samorządowej, Rzeszów 2006, s. 545.

${ }_{28}$ T. Bojar-Fijałkowski, Dostęp do informacji publicznej - wybrane zagadnienia materialnoprawne i proceduralne z uwzględnieniem informacji o środowisku i jego ochronie jako szczególnego rodzaju informacji publicznej, [w:] A. Lusińska, A. Kalinowska-Żeleźnik (red.), Dostęp do informacji publicznej. Wybrane aspekty teorii i praktyki, Gdańsk 2014, s. 9 i n.

${ }_{29}$ M. Jabłoński, Udostępnianie informacji publicznej w trybie wnioskowym, Wrocław 2009, s. 105.

${ }^{30}$ M. Jabłoński, K. Wygoda, Dostęp do informacji i jego granice, „Acta Universitatis Wratislaviensis" 2002, s. 112.

${ }^{31}$ G. Cern, T. Bojar-Fijałkowski, Uprawnienia mieszkańców jednostek samorzadu terytorialnego w zakresie dostępu do informacji publicznej, „Filozofia Publiczna i Edukacja Demokratyczna" 2014, nr 1, s. 159.

${ }^{32}$ M. Jaśkowska, Dostęp do informacji publicznych w świetle orzecznictwa, s. 26. 
Dlatego też zdaniem M. Jaśkowskiej wyliczenie zawarte w art. 6 UDIP ma charakter wyłącznie przykładowy, pozwala jednak zorientować się, do jakiego typu stanów faktycznych odnosi się dane pojęcie ${ }^{33}$. Także P. Szustakiewicz zauważa, że możliwe jest rozszerzanie tego katalogu poprzez udostępnianie innych informacji, które w świetle UDIP będą wchodziły w zakres pojęciowy terminu „informacja publiczna” ${ }^{34}$.

Wielu przedstawicieli doktryny jest zwolennikami tzw. modelu szerokiego ujęcia sprawy publicznej, który zakłada, że każda informacja znajdująca się w posiadaniu podmiotu publicznego jest informacją publiczną ${ }^{35}$.

Jak zauważono, teoretycznie tak szerokie rozumienie informacji publicznej pozwala suwerenowi na dostęp do informacji o procesach decyzyjnych, jego uczestnikach, stanowiskach władzy publicznej i grup interesu na nią oddziaływujący ch $^{36}$. Jednak w orzecznictwie sądów administracyjnych przyjęto znacznie węższe ujęcie informacji publicznej. Jak stwierdził Naczelny Sąd Administracyjny w 2012 r., informację publiczną stanowią wyłącznie dane obiektywne lub fakty, a nie kwestie ocenne czy postulatywne ${ }^{37}$.

Odnośnie do zakresu przedmiotowego informacji publicznej w orzecznictwie administracyjnym kontynuowana jest linia orzecznicza zapoczątkowana przez NSA, który orzekł, że informacją publiczną w rozumieniu ustawy będzie każda wiadomość wytworzona lub odnoszona do władz publicznych, a także wytworzona lub odnoszona do innych podmiotów wykonujących funkcje publiczne w zakresie wykonywania przez nie zadań władzy publicznej ${ }^{38}$. Informacja publiczna dotyczy sfery faktów ${ }^{39}$. Stanowi ją treść wszelkiego rodzaju dokumentów odnoszących się do organu władzy publicznej i dotyczących sfery jego działalności. Bez znaczenia jest

33 Tamże.

${ }^{34}$ P. Szustakiewicz, Dostęp do informacji na podstawie ustawy o dostępie do informacji publicznej, [w:] T. Gardocka (red.), Obywatelskie prawo do informacji, Warszawa 2008, s. 21.

${ }_{35}$ M. Bernaczyk, Obowiazek bezwnioskowego udostępniania informacji publicznej, Warszawa 2008.

36 B. Banaszak, M. Bernaczyk, Konsultacje społeczne i prawo do informacji o procesie prawotwórczym na tle Konstytucji RP oraz postulatu "otwartego rządu”, "Zeszyty Naukowe Sądownictwa Administracyjnego" 2012, nr 4, s. 23-24.

${ }^{37}$ Wyrok Naczelnego Sądu Administracyjnego z 27 stycznia 2012 r., I OSK 2130/11, CBOSA.

${ }^{38}$ Wyrok Naczelnego Sądu Administracyjnego z 25 marca 2003 r., II SA 4059/02, CBOSA.

${ }^{39}$ Wyrok Naczelnego Sądu Administracyjnego z 29 lutego 2012 r., I OSK 2215/11, CBOSA. 
to, w jaki sposób dokumenty te znalazły się w posiadaniu organu i jakiej sprawy dotyczą. Ważne natomiast jest, by dokumenty takie służyły realizowaniu zadań publicznych przez organ i odnosiły się do niego bezpośrednio ${ }^{40}$.

Stosownie do art. 4 ust. 1 UDIP obowiązane do udostępniania informacji publicznej są władze publiczne oraz inne podmioty wykonujące zadania publiczne, w szczególności: organy władzy publicznej; organy samorządów gospodarczych i zawodowych; podmioty reprezentujące zgodnie z odrębnymi przepisami Skarb Państwa; podmioty reprezentujące państwowe osoby prawne albo osoby prawne samorządu terytorialnego oraz podmioty reprezentujące inne państwowe jednostki organizacyjne albo jednostki organizacyjne samorządu terytorialnego; podmioty reprezentujące inne osoby lub jednostki organizacyjne, które wykonują zadania publiczne lub dysponują majątkiem publicznym, oraz osoby prawne, w których Skarb Państwa, jednostki samorządu terytorialnego lub samorządu gospodarczego albo zawodowego mają pozycję dominującą w rozumieniu przepisów o ochronie konkurencji i konsumentów.

Partii politycznych dotyczy natomiast bezpośrednio art. 4 ust. 2 wzmiankowanej ustawy, zgodnie z którym obowiązane do udostępnienia informacji publicznej są organizacje związkowe i pracodawców, reprezentatywne w rozumieniu ustawy o Radzie Dialogu Społecznego ${ }^{41}$, oraz partie polityczne. W ślad za ustawa, $\mathrm{w}$ doktrynie umiejscawia się partie w trzeciej kategorii podmiotów zobowiązanych do udostępniania informacji, po organach władzy publicznej oraz po innych podmiotach wykonujących zadania publiczne, a razem ze związkami zawodowymi i ich organizacjami ${ }^{42}$.

Ustawodawca inaczej zatem niż ustrojodawca określił sposób definiowania zobowiązanego do udostępniania informacji publicznych, rozsze-

${ }^{40}$ Wyrok Naczelnego Sądu Administracyjnego z 27 marca 2012 r., I OSK 155/12, CBOSA.

${ }^{41}$ Ustawa z dnia 24 lipca 2015 r. o Radzie Dialogu Społecznego i innych instytucjach dialogu społecznego (Dz. U. poz. 1240).

${ }^{42}$ M. Jaśkowska, Dostęp do informacji publicznej-zagadnienia wybrane, materiał na Konferencję sędziów NSA, Popowo 14-16 października 2002 r., Warszawa 2002, s. 8, cyt. za: S.M. Pietras, P. Szustakiewicz, Podmioty zobowiazane do udzielenia informacji publicznej w rozumieniu art. 4 ustawy z dnia 6 września 2001 r. o dostępie do informacji publicznej, „Ius Novum” 2001, nr 4, s. 109. 
rzając podmiotowy krąg zobowiązanych ${ }^{43}$ i odwołując się do koncepcji otwartego sposobu identyfikacji. Faktyczne uczestniczenie określonej osoby oraz jednostki organizacyjnej (nawet takiej, która nie jest podmiotem prawa publicznego) w procesie realizacji władztwa publicznoprawnego, jeżeli wiąże się ono wyłącznie z realizacją zadania publicznego (bądź tylko korzystania z majątku publicznego), może stać się przesłanką powstania po stronie takiego podmiotu obowiązku udostępniania informacji publicznej ${ }^{44}$.

Przepisy UDIP nie są niestety w pełni jasne i spójne z uregulowaniami konstytucyjnymi, co stało się przedmiotem krytyki w doktrynie. Krytyka dotyczy również tego, że ustawodawca, rozszerzając zakres podmiotowy normy konstytucyjnej, zarazem pozostawił niektóre podmioty wymienione $\mathrm{w}$ tej normie poza ustawowym obowiązkiem informowania. Art. 61 Konstytucji wyraźnie wskazuje bowiem, że prawo do informacji przysługuje również obywatelowi od osób pełniących funkcje publiczne, o których UDIP nie wspomina. Nie można bowiem przyjąć, że pojęcie to jest zawsze tożsame $\mathrm{z}$ „organami władzy publicznej” lub „innymi podmiotami wykonującymi zadania publiczne" ${ }^{\prime 4}$.

Kontrowersyjne jest również pojęcie „dysponowania majątkiem publicznym". Jak wskazuje się w literaturze, gdyby przyjąć wykładnię literalna, to ciężar udostępniania informacji publicznych zostałby przeniesiony na podmioty prywatne, np. na osobę dzierżawiącą od gminy grunt ${ }^{46}$, zaś gdyby utożsamić dysponowanie majątkiem publicznym z gospodarowaniem środkami publicznymi, to ciężar ten dotyczyłby np. osoby fizycznej, która uzyskała dofinansowanie na realizację projektu naukowego ${ }^{47}$.

W doktrynie przyjmuje się podział podmiotów zobowiązanych do udostępnienia informacji na organy administracji publicznej oraz tzw. organy administrujące. P. Sitniewski ujmuje wykonywanie zadania publicznego jako administrowanie wycinkiem sfery publicznej ${ }^{48}$.

43 A. Błaszczyńska, Zakres podmiotowy prawa do informacji publicznej, „Przegląd Prawa Publicznego" 2010, nr 6.

${ }^{44}$ M. Jabłoński, Prawo dostępu do informacji publicznej a prawo petycji, [w:] R. Balicki, M. Jabłoński (red.), Teoretyczne i praktyczne aspekty realizacji prawa petycji, Wrocław 2015, s. 324 .

45 A. Piskorz-Ryń, Dostęp do informacji publicznej, s. 199.

${ }^{46}$ B. Dolnicki, R. Cybulska, Realizacja zasady jawności i dostępu, s. 19.

${ }^{47}$ K. Tarnacka, Prawo do informacji w polskim, s. 161.

${ }^{48}$ P. Sitniewski, Ustawa o dostępie do informacji publicznej. Komentarz, Wrocław 2011, s. 81. 
Według M. Jabłońskiego ustalenie, czy podmiot spoza pierwszego zbioru jest zobowiązany do udostępnienia informacji publicznej wymaga odpowiedzi na pewne pytania, m.in. czy zadanie przezeń wykonywane jest zadaniem publicznym i czy istnieje publicznoprawna podstawa jego wykonywania (np. porozumienie, umowa, decyzja); czy dany podmiot w zakresie wykonywania zadania dysponuje majątkiem publicznym oraz czy jest on pod tym względem objęty kontrolą Najwyższej Izby Kontroli ${ }^{49}$. Zdaniem K. Izdebskiego jedynym, ale niesamoistnym elementem odnoszącym się do przesłanek uznania za podmiot zobowiązany do udostępniania informacji publicznej, jest fakt wykonywania zadań publicznych na zlecenie organów władzy publicznej ${ }^{50}$. Podobnie S. Czarnow zauważył, że dla traktowania danej informacji jako publicznej decydujące powinno być nie samo jej wytworzenie, lecz fakt, iż została pozyskana i przetworzona w celu realizacji zadań publicznych ${ }^{51}$. Sformułowanie „w szczególności” oznacza, że każdy podmiot, również np. organizacja pozarządowa, jest zobowiązany do udostępnienia informacji publicznej, jeśli wykonuje zadania publiczne i ma takie informacje ${ }^{52}$.

Z kolei M. Jaśkowska proponuje podział podmiotów na trzy kategorie: organy władzy publicznej, inne podmioty wykonujące zadania publiczne oraz związki zawodowe (i ich organizacje) i partie polityczne ${ }^{53}$.

Regulacje UDIP spotkały się z zasłużoną krytyką w doktrynie, wielu autorów wyraża pogląd, że kolejne nowelizacje ustawy wprowadziły jeszcze większe zamieszanie i trudności $\mathrm{w}$ racjonalnym stosowaniu jej przepisów $^{54}$. Z biegiem lat narastają wątpliwości dotyczące tego aktu, czego wymownym przykładem jest ewolucja poglądów M. Jabłońskiego. O ile w 2009 r. wyraził on pozytywną ocenę ustawy, iż „przetrwała ona próbę

${ }^{49}$ M. Jabłoński, Udostępnienie informacji publicznej w trybie wnioskowym, Wrocław 2009, s. 118 .

${ }^{50}$ K. Izdebski, Wykonywanie zadań organów administracji jako przesłanka udostępniania informacji publicznej, „Przegląd Naukowy Disputatio” 2013, t. XVI, s. 21.

51 S. Czarnow, Prawo do informacji publicznej w Polsce a wymogi prawa europejskiego, "Samorząd Terytorialny" 2007, nr 4.

${ }_{52}$ T.R. Aleksandrowicz, Komentarz do ustawy o dostępie, s. 91.

${ }^{53}$ M. Jaśkowska, Dostęp do informacji publicznej - zagadnienia wybrane, s. 8.

${ }^{54}$ Taż, Jakość i spójność rozwiązań prawnych w świetle nowelizacji ustawy o dostępie do informacji publicznej, [w:] D.R. Kijowski, P.J. Suwaj (red.), Kryzys prawa administracyjnego?, t. 1, Warszawa 2012, s. 369-386; M. Jabłoński, Prawo do ponownego wykorzystania informacji publicznej - nowy etap rozwoju prawa do informacji, [w:] R. Balicki, M. Masternak-Kubiak (red.), W stużbie dobru wspólnemu. Księga Jubileuszowa dedykowana Profesorowi Januszowi Trzcińskiemu, Warszawa 2012, s. 197. 
czasu” 55, o tyle już w 2013 r. wyartykułował wątpliwość, czy ustawa „wyraża ducha Konstytucji RP"56.

M. Bernaczyk wskazuje, że często nie da się przeprowadzić precyzyjnego rozróżnienia pomiędzy faktem a oceną, w związku z czym w innych państwach demokratycznych zostało ono porzucone. W Polsce natomiast mechanizm ten jest stosowany powszechnie w judykaturze, zaś ustawodawca nie dostrzega potrzeby jakichkolwiek zmian w tym zakresie ${ }^{57}$.

Jak słusznie zauważono, liczne katalogi podmiotów oraz praktycznie nieograniczone spektrum przedmiotowe tworzą niezwykle skomplikowany, ale zarazem liberalny system jednostek o często nieprecyzyjnych prawach i obowiązkach. Dlatego też szczególną rolę w konstytucyjnym prawie dostępu do informacji przyznać należy sądom ${ }^{58}$.

Dorobek judykatury w zakresie powyższej problematyki nie jest zbyt bogaty, co zostało wspomniane na wstępie niniejszego opracowania, jednakże wystarczający do zasygnalizowania problemów prawnych pojawiających się na styku politycznej aktywności partyjnej oraz udostępniania informacji publicznej.

\section{Zakres elementu publicznego w działalności partii politycznych na tle orzecznictwa sądów administracyjnych}

Przechodząc do omówienia problemów związanych z udostępnianiem informacji mających charakter specyficzny dla kategorii podmiotów, jakimi są partie polityczne, trzeba zwrócić uwagę, że kluczowym zagadnieniem jest bez wątpienia zakres „elementu publicznego” w działalności partyjnej.

W orzecznictwie administracyjnym napotkać możemy coraz częściej stanowisko, że każda partia polityczna spełnia funkcje publiczne ${ }^{59}$. Obo-

55 M. Jabłoński, Udostępnianie informacji publicznej w trybie, s. 261.

${ }_{56}$ Tenże, Udostępnianie informacji publicznej w formie wgladu do dokumentu, Wrocław 2013, s. 227.

${ }^{57}$ M. Bernaczyk, Prawo do informacji publicznej w Polsce i na świecie, Warszawa 2014, s. 171 .

${ }^{58}$ M. Bidziński, Konstytucyjne prawo dostępu do informacji publicznej, „Przegląd Prawa Konstytucyjnego" 2012, nr 4, s. 133.

${ }_{59}$ Wyrok Naczelnego Sądu Administracyjnego z 27 czerwca 2013 r., I OSK 513/13; wyrok Wojewódzkiego Sądu Administracyjnego w Warszawie z 6 listopada 2013 r., II SAB/ 
wiązki wynikające z UDIP aktualizują się w odniesieniu do każdej posiadanej przez partię informacji o znaczeniu publicznym. Jak zauważył sąd, nie chodzi zatem o każdą informację związaną z funkcjonowaniem partii politycznej, lecz taka, która wiąże się z elementem publicznym ${ }^{60}$. W odniesieniu do partii parlamentarnej sąd stwierdził, że uczestnictwo tej partii w wyborach, rejestracja komitetów wyborczych i kandydatów, udział partii we władzy ustawodawczej, a także we władzy parlamentarnej Unii Europejskiej, potencjalny lub realny wpływ na obsadzanie stanowisk publicznych oraz finansowanie działalności z budżetu państwa są przejawami aktywności w sferze publicznej, związanej z polityką państwa, a informacje na ten temat dotyczą spraw publicznych ${ }^{61}$.

Często przytaczany w orzecznictwie jest wywód warszawskiego sądu, który skonstatował, że jeżeli działania partii dotyczą sfery publicznej (w szerokim rozumieniu zakresu semantycznego definicji zawartej w art. 1 ust. 1UDIP), to dokumenty wytworzone $\mathrm{w}$ wyniku takich działań stanowią przedmiot informacji publicznej w rozumieniu tejże ustawy. Jak zauważył skład orzekający, z samej istoty partii politycznej - publicznego celu jej działania, udziału w życiu publicznym trudno jest wskazać takie aspekty działania, które przymiotu publicznego by nie miały ${ }^{62}$.

Powyższe stanowisko sądownictwa administracyjnego pozostaje spójne z poglądem wyrażonym przez Trybunał Konstytucyjny, który zauważył, że państwo akceptuje zasadniczą funkcję partii w systemie demokratycznym i uznaje prawo partii politycznych do wpływania na kształtowanie polityki państwa. Jest to funkcja publiczna, ściśle związana z władzą państwową. Partie, stanowiąc element systemu politycznego, są podstawową instytucją publicznego życia politycznego ${ }^{63}$. Ten pogląd posiada solidne oparcie $\mathrm{w}$ doktrynie prawa. Jej ugruntowane stanowisko głosi, że wprawdzie partie polityczne nie są organami władzy publicznej, jednak sama logika ich istnienia wskazuje na dążenie do zdobycia władzy

Wa 447/13; wyrok Wojewódzkiego Sądu Administracyjnego w Warszawie z 21 listopada 2013 r., I SAB/Wa 416/13; wyrok Wojewódzkiego Sądu Administracyjnego w Warszawie z 30 czerwca 2016 r., II SAB/Wa 164/16; CBOSA.

${ }^{60}$ Wyrok Wojewódzkiego Sądu Administracyjnego w Warszawie z 5 lutego 2015 r., II SAB/Wa 661/14, CBOSA.

61 Tamże.

${ }^{62}$ Wyrok Wojewódzkiego Sądu Administracyjnego w Warszawie z 12 stycznia 2015 r., II SAB/Wa 855/14, CBOSA.

${ }^{63}$ Wyrok Trybunału Konstytucyjnego z 14 grudnia 2004 r., K 25/03 (Dz. U. Nr 273, poz. 2721). 
lub przynajmniej uzyskanie wpływu na władzę ${ }^{64}$. Również przedstawiciele nauk politologicznych wyrażają pogląd, że podstawową dominantą definicji partii politycznych jest element „dążenia do zdobycia lub utrzymania władzy"65.

Przepisy konstytucyjne odnoszące się do partii świadczą o nadaniu im przez ustawodawcę rangi podstawowej instytucji publicznej życia politycznego ${ }^{66}$. Przyjął on milczące założenie, iż partie polityczne wykonują zadania publiczne $\mathrm{z}$ samej definicji, bowiem $\mathrm{w}$ takim celu zostały powołane do życia ${ }^{67}$. Jako motywy ustawowego objęcia partii politycznych oraz związków zawodowych obowiązkiem udostępniania informacji wymieniane są: rodzaj wykonywanej przez nie działalności bądź korzystanie z majątku publicznego, a także możliwości szerokiego dysponowania informacjami o charakterze publicznym ${ }^{68}$.

Przedstawiciele nauki prawa kładą nacisk na publiczną funkcję partii politycznych pełnioną przez nie w obecnym systemie konstytucyjnym i politycznym państwa, co odbywa się kosztem funkcji partii politycznych jako podmiotów prywatnoprawnych ${ }^{69}$. W literaturze określa się partię polityczną jako wyspecjalizowaną organizację społeczną posiadającą określony program, będący podstawą do uzyskania szerszego poparcia społecznego i do zdobycia władzy oraz maksymalizacji pozycji w systemie politycznym ${ }^{70}$.

Nieco inny pogląd wyraził natomiast NSA w 2014 r. podkreślając, że $\mathrm{w}$ demokratycznym państwie prawnym partie polityczne nie sprawują władzy publicznej, ani nie wykonują zadań publicznych ${ }^{71}$. Powołując się

${ }^{64}$ M. Chmaj (red.), Wolności i prawa człowieka w Konstytucji Rzeczypospolitej Polskiej, Warszawa 2008, s. 132.

${ }^{65}$ M. Drzonek, Wielokadencyjność bez afiliacji partyjnej? Spostrzeżenia po reelekcjach „wiecznych prezydentów" w 2014 r., „Przegląd Politologiczny” 2016, nr 1, s. 83 i przywołana tam literatura polska oraz zagraniczna.

${ }^{66}$ J. Majchrowski, Partie polityczne w świetle nowej Konstytucji, „Państwo i Prawo” 1997, nr 11-12, s. 169.

${ }_{67}$ T.R. Aleksandrowicz, Komentarz do ustawy o dostępie, s. 93.

${ }_{68}$ M. Jaśkowska, Dostęp do informacji publicznych w świetle orzecznictwa, s. 45.

${ }_{69}$ M. Aleksandrowicz, A. Jamróz, J. Jamróz (red.), Demokratyczne państwo prawa. Zagadnienia wybrane, Białystok 2014, s. 303.

${ }^{70}$ M. Chmaj, W. Sokół, M. Żmigrodzki, Teoria partii politycznych, Lublin 1997, s. 15.

${ }^{71}$ Wyrok Naczelnego Sądu Administracyjnego z 26 listopada 2014 r., I OSK 633/14, CBOSA. 
na art. 6 ustawy o partiach politycznych ${ }^{72}$, zgodnie z którym partie polityczne nie mogą wykonywać zadań zastrzeżonych w przepisach prawa dla organów władzy publicznej ani zastępować tych organów w wykonywaniu ich zadań; sąd skonstatował, że partie polityczne nie wykonują samodzielnie władzy publicznej, wpływają natomiast na jej sprawowanie. Informacje niedotyczące wydatkowania przez partię polityczną środków finansowych mogłyby być uznane za informację publiczna, gdyby dotyczyły wykonywania przez zobowiązany podmiot zadań publicznych ${ }^{73}$.

NSA nie wypracował jak dotąd $\mathrm{w}$ tym zakresie jednolitego orzecznictwa. W powołanym już wcześniej orzeczeniu ${ }^{74}$ wyrażone zostało stanowisko wręcz rażąco przeciwne. Skład orzekający w ogóle nie odniósł się bowiem do argumentacji sądu niższej instancji, ograniczając się do konstatacji o pełnieniu przez partię funkcji publicznych i wyprowadzając $\mathrm{z}$ tego stwierdzenia tezę przyznającą żądanym informacjom walor informacji publicznej.

Najważniejsza z kwestii, jakie należy rozstrzygnąć na tle rozbieżnych stanowisk składów orzekających sądów administracyjnych dotyczy tego, jak rozumieć zakres elementu publicznego w działalności partii politycznych i w jaki sposób przekłada się on na istnienie lub nieistnienie obowiązku udostępnienia informacji przez partię na podstawie UDIP.

Powstaje zatem pytanie, czy "element publiczny”, o którym mowa, należy utożsamiać z funkcjami publicznymi, jakie spełnia każda partia polityczna, czy też z pojęciem zadań publicznych, których partie nie wykonują. Jeżeli zaś wiązać go z funkcjami, to czy pojmować jako uniwersalną podstawę słuszności żądań o udostępnianie jakichkolwiek informacji przez partię polityczną czy też każdorazowo rozpatrywać obecność i zakres elementu publicznego w danej informacji, o którą toczy się spór. Racjonalne i znajdujące oparcie w doktrynie wydaje się to ostatnie podejście.

Dokonanie pogłębionej analizy tematu wymaga odpowiedzi na pytanie, czy każda partia polityczna spełnia funkcje publiczne. Znaczna część doktryny oraz orzecznictwa administracyjnego, a także linia orzecznicza

${ }^{72}$ Ustawa z dnia 27 czerwca 1997 r. o partiach politycznych (tekst jedn. Dz. U. z 2011 r. Nr 155, poz. 924 z późn. zm.), (dalej: UPP).

${ }^{73}$ Wyrok Naczelnego Sądu Administracyjnego z 26 listopada 2014 r., I OSK 633/14, CBOSA.

${ }^{74}$ Wyrok Naczelnego Sądu Administracyjnego z 27 czerwca 2013 r., I OSK 513/13, CBOSA. 
TK udzieliła na to pytanie odpowiedzi pozytywnej, co zostało już omówione $^{75}$.

Pytanie drugie dotyczy wykonywania przez partie zadań publicznych. Pojęcie to należy najpierw zdefiniować. Nie posiada ono definicji legalnej $^{76}$, cechuje je zmienność w czasie i w przestrzeni ${ }^{77}$. W ujęciu L. Zacharko jest to obowiązek administracyjny stanowiący konkretyzację celu działania organu administracji ${ }^{78}$, natomiast według $\mathrm{M}$. Tabernackiej zadanie publiczne to określony normatywnie obowiązek działania, do realizacji którego, na podstawie kompetencji określonej prawem, właściwemu organowi przysługują przyznane prawem formy działania ${ }^{79}$. S. Fundowicz, opierając się na znanej definicji administracji w ujęciu J. Bocia ${ }^{80}$, określił zadanie publiczne jako przejęte przez państwo zaspokajanie zbiorowych i indywidualnych potrzeb człowieka, wynikających ze współżycia ludzi w społecznościach ${ }^{81}$. Według S. Biernata podstawowym kryterium uznania konkretnego zadania za zadanie publiczne powinno być ponoszenie odpowiedzialności za jego realizację przez administrację publiczna, nawet jeśli wykonawca znajduje się poza strukturami administracji ${ }^{82}$. Zagadnienie zadań publicznych posiada obszerny dorobek $w$ doktrynie polskiej oraz szczególnie w niemieckiej, którego omówienie wykracza poza ramy

75 Oprócz publikacji oraz orzeczeń przytoczonych w niniejszym opracowaniu zob. np. W. Skrzydło, Konstytucja Rzeczypospolitej Polskiej. Komentarz, Kraków 2000; M. Granat, P. Policastro, J. Sobczak (red.), Partie polityczne we wspótczesnym konstytucjonalizmie, Lublin 2001; D. Dudek, Zasady ustroju III Rzeczypospolitej Polskiej, Warszawa 2009; J. Majchrowski, Partie polityczne w Polsce wspótczesnej: między konstytucyjnym ideałem a ustawowa rzeczywistościa, „Studia Iuridica” 2013, t. 56; A. Bień-Kacała, Problematyka partii politycznych w orzecznictwie Trybunału Konstytucyjnego, „Toruńskie Studia Polsko-Włoskie” 2016, t. XII.

${ }^{76}$ R. Stasikowski, O pojęciu zadań publicznych (studium z zakresu nauki administracji i nauki prawa administracyjnego), „Samorząd Terytorialny” 2009, nr 7-8.

77 I. Sierpowska, Pomoc społeczna jako administracja świadczaca. Studium administracyjnoprawne, Warszawa 2012, s. 183.

${ }^{78}$ L. Zacharko, Prywatyzacja zadań publicznych gminy. Studium administracyjno-prawne, Katowice 2000, s. 16-17.

${ }^{79}$ M. Tabernacka, Zakres wykonywania zadań publicznych przez organy samorzadów zawodowych, Wrocław 2007, s. 82.

80 J. Boć (red.), Prawo administracyjne, Wrocław 2004, s. 16.

${ }^{81}$ S. Fundowicz, Dynamiczne rozumienie zadania publicznego, [w:] J. Supernat (red.), Między tradycja a przyszłościa w nauce prawa administracyjnego. Księga jubileuszowa dedykowana Profesorowi Janowi Bociowi, Wrocław 2009, s. 158.

${ }_{22}$ S. Biernat, Prywatyzacja zadań publicznych. Problematyka prawna, Warszawa-Kraków 1994, s. 25-34. 
niniejszego opracowania ${ }^{83}$. Przedstawiciele nauki pozostają zgodni co do tego, że o uznaniu zadania za publiczne decyduje samodzielnie i ostatecznie państwo ${ }^{84}$.

Negatywna odpowiedź na pytanie o kwestię wykonywania zadań publicznych przez partie polityczne została wielokrotnie udzielona przez ustawodawcę. Przede wszystkim należy tu wymienić UPP, która w art. 6 stanowi, że partie polityczne nie mogą wykonywać zadań zastrzeżonych w przepisach prawa dla organów władzy publicznej ani zastępować tych organów w wykonywaniu ich zadań. Przepisy UPP są uzupełnione przez regulacje innych aktów ustawowych. Partie polityczne nie zostały np. uwzględnione przez ustawodawcę $\mathrm{w}$ systemie partnerstwa $\mathrm{z}$ organizacjami społecznymi w wykonywaniu zadań publicznych (art. 2 ustawy o pomocy społecznej ${ }^{85}$ ). Należy to oceniać jako z jednej strony ujęcie prawidłowe, a z drugiej wskazujące na to, że katalog ten nie może być rozszerzany $^{86}$. Z kolei ustawa o działalności pożytku publicznego i wolontariacie ${ }^{87} \mathrm{w}$ art. 3 ust. 4 pkt 1 i 5 wyklucza prowadzenie działalności pożytku publicznego w sferze zadań publicznych przez partie polityczne oraz fundacje utworzone przez te partie.

Jak wynika z orzecznictwa, wykonywanie zadań publicznych zawsze wiąże się z realizacją podstawowych publicznych praw podmiotowych obywateli $^{88}$. Partia polityczna - jako dobrowolna organizacja opierająca swoją działalność na pracy społecznej członków - nie realizuje publicznych praw podmiotowych obywateli, tzn. nie przydaje uprawnień jednostkom, jak też nie nakłada na nie obowiązków, jak czynią to organy władzy publicznej ${ }^{89}$. W judykaturze nie ulega też wątpliwości, że partie polityczne nie należą do

${ }^{83}$ Wnikliwe zestawienie poglądów polskiej i niemieckiej nauki prawa w tym zakresie przedstawił R. Stasikowski, O pojęciu zadań publicznych.

${ }^{84}$ M. Stahl, Cele publiczne i zadania publiczne, [w:] J. Zimmermann (red.), Koncepcja systemu prawa administracyjnego, Warszawa 2007, s. 95.

${ }^{85}$ Ustawa z dnia 12 marca 2004 r. o pomocy społecznej (tekst jedn. Dz. U. z 2016 r. poz. 930 z późn. zm.).

${ }^{86}$ S. Nitecki, Udział podmiotów niepublicznych w realizacji zadań pomocy społecznej, „Roczniki Administracji i Prawa” 2012, t. XII, s. 108.

${ }^{87}$ Ustawa z dnia 24 kwietnia 2003 r. o działalności pożytku publicznego i wolontariacie (tekst jedn. Dz. U. z 2016 r. poz. 1817 z późn. zm.).

${ }^{88}$ Wyrok Naczelnego Sądu Administracyjnego z 18 sierpnia 2010 r., I OSK 851/10, CBOSA.

${ }^{89}$ Wyrok Wojewódzkiego Sądu Administracyjnego w Warszawie z 7 czerwca 2016 r., II SAB/Wa 113/16, CBOSA. 
podmiotów wymienionych $\mathrm{w}$ art. 4 ust. 1 UDIP $^{90}$. Zgodzić się należy z poglądem, że $w$ demokratycznym państwie prawnym partie polityczne nie sprawują władzy publicznej, ani nie wykonują zadań publicznych ${ }^{91}$.

Prowadzi to do następnego punktu rozważań, a mianowicie: czy za podstawę istnienia bądź nieistnienia przymiotu „publiczności” w odniesieniu do partii uznać wykonywanie funkcji publicznych czy też niewykonywanie zadań publicznych? Obydwa te stanowiska znajdują swoje odzwierciedlenie w orzecznictwie, co zostało przytoczone wcześniej. Konsekwencją pierwszego z nich jest przyjęcie, że niemal cała aktywność partii politycznych odnosi się do sfery publicznej, drugiego zaś, że tylko te elementy, które dotyczą zadań publicznych. Na to rozróżnienie nałożyć niejako trzeba inny podział, który dotyczy odmiennego postrzegania relacji pomiędzy art. 4 ust. $1 \mathrm{i}$ art. 4 ust. 2 UDIP. Istnieje więc pogląd, który rozróżnienie pomiędzy podmiotami wymienionymi w obu tych artykułach nazywa sztucznym oraz drugi, który to rozróżnienie z całą mocą podkreśla i wyciąga z niego daleko idące wnioski. Rzecz jasna, przypisywanie przymiotu „publiczności” na gruncie UDIP pełnieniu przez partie funkcji publicznych powiązane jest zazwyczaj z lekceważeniem w mniejszym lub większym stopniu powyższego podziału podmiotów, w ustawie zaś powiązanie wspomnianej „publiczności” z wykonywaniem zadań publicznych sprzyja z kolei podkreślaniu rozbieżności pomiędzy ustawowym ujęciem obu kategorii podmiotów.

Prowadzi to do alternatywy skrajności: przyjęcie, że w odniesieniu do partii politycznych jawność jest reguła, tajność zaś wyjątkiem, co stanowi niemalże zrównanie tych podmiotów z organami administracji publicznej - albo ustanowienie zasady odwrotnej, czyniącej jawność wyjątkiem nieodłącznie związanym z pozyskiwaniem i wydatkowaniem środków finansowych. Pierwsza skrajność wydaje się pozostawać w sprzeczności $\mathrm{z}$ zasadą racjonalnego ustawodawcy, w myśl której istnieje ratio legis wyłączenia partii politycznych z katalogu podmiotów ujętych w art. 4 ust. 1 UDIP. Skrajność druga nie posiada tej wady, jednakże przekreśla dotychczasowy dorobek doktryny i orzecznictwa w zakresie uznania doniosłej roli partii politycznych w sferze publicznej.

Wychodząc zatem ze stanowiska pierwszego, czyli uznając doniosłość pełnienia przez partie funkcji publicznych i uwzględniając zarazem

90 Wyrok Naczelnego Sądu Administracyjnego z 26 listopada 2014 r., I OSK 633/14; wyrok Naczelnego Sądu Administracyjnego z 18 grudnia 2014 r., I OSK 611/14; CBOSA.

${ }^{91}$ Wyrok Naczelnego Sądu Administracyjnego z 26 listopada 2014 r., I OSK 633/14, CBOSA. 
znaczenie ustawowego rozróżnienia pomiędzy podmiotami z art. 4 ust. 1 i art. 4 ust. 2 UDIP, które można uzasadnić właśnie brakiem wykonywania przez partie zadań publicznych - dochodzimy do konkluzji, że należy badać istnienie bądź nieistnienie elementu publicznego w każdej konkretnej sprawie, wyjąwszy sferę informacji dotyczącej pozyskiwania i wydatkowania środków finansowych, co wynika z przepisów szczególnych. Nie należy zatem z góry przesądzać przymiotu „publiczności”, opierając się na argumencie funkcji publicznych, ani też z góry go wykluczać powołując się na argument zadań publicznych. O ile zatem jawność działalności podmiotów $\mathrm{z}$ art. 4 ust. 1 została ukształtowana ustawowo, o tyle jawność działalności podmiotów z art. 4 ust. 2 winna być kształtowana sądowo (rzecz jasna na podstawie ustawy), poprzez ważenie elementu publicznego w każdej sprawie. Pozwoli to na rozwiązanie problemu przy poszanowaniu dorobku doktryny i orzecznictwa konstytucyjnego, łącząc zarazem różne rozdzielne wątki z orzecznictwa sądów administracyjnych.

\section{Udostępnianie informacji o finansach partii politycznych}

Szereg zagadnień, które posiadają istotne znaczenie dla kierunku, w jakim ewoluować będzie orzecznictwo dotyczące udostępniania informacji publicznych przez partie związany jest z ich finansowaniem, np. kwestia, czy wydatkowanie środków finansowych przez partię polityczną jest informacją publiczną. Przed omówieniem orzecznictwa, które pozostaje i w tym zakresie rozbieżne, warto spojrzeć na ogólne zagadnienie finansowania partii politycznych oraz udostępniania stosownych informacji.

Częściowe lub całkowite finansowanie partii politycznych z budżetu państwa służyć ma m.in. zapobieżeniu przekształcenia się partii w pogoni za zyskiem $\mathrm{w}$ dochodowe przedsiębiorstwa; uwolnieniu ich spod nacisku zorganizowanych grup interesów partykularnych; wyrównaniu szans partii w systemie partyjnym; stworzeniu finansowych gwarancji dla stałej działalności polityczno-organizacyjnej wykonywanej przez partie; stabilizacji systemu partyjnego ${ }^{92}$. Jest ono traktowane jako oznaka przemiany swobodnej współpracy dobrowolnie zrzeszających się ludzi we

${ }_{92}$ M. Chmaj, Finansowanie partii politycznych, [w:] M. Chmaj (red.), Finansowanie polityki w Polsce na tle europejskim, Torun 2008, s. 164. 
współorganizowaną przez państwo partycypację w szeroko rozumianym rządzeniu ${ }^{93}$. Finansowanie kampanii wyborczej jest postrzegane nie tylko przez pryzmat potrzeb partii politycznych, indywidualnych kandydatów, rywalizacyjnego charakteru wyborów, ale również w kontekście ochrony podstawowych interesów państwa ${ }^{94}$.

System ten nie jest jednak pozbawiony elementów negatywnych. Warto $\mathrm{w}$ tym kontekście przytoczyć opinię wyrażaną w naukach politologicznych, że finansowanie partii politycznych z budżetu państwa bezpośrednio wpływa na konkurencję w ramach systemu partyjnego oraz izoluje go od woli suwerena, co równie dobrze może być interpretowane jako delegitymizujące działania wobec samego systemu demokratycznego. Konsekwencją tego finansowania jest pogłębianie dystansu między partiami a społeczeństwem, w rezultacie czego zamknięty może zostać istotny kanał dla wyrażania społecznych interesów i ograniczony społeczny udział w polityce ${ }^{95}$.

W Polsce obowiązuje (oceniany $\mathrm{w}$ doktrynie jako optymalny $\mathrm{w}$ porównaniu do liberalnego i restrykcyjnego ${ }^{96}$ ) mieszany model finansowania partii politycznych, który pozwala im czerpać pożytki zarówno od podmiotów prywatnych, jak i ze środków budżetowych. Te ostatnie pozostają jednak najważniejszym źródłem majątku partii, a uzyskanie do nich prawa daje partiom znaczną przewagę nad konkurencją która tego prawa nie posiada ${ }^{97}$. Jak zauważył K. Skotnicki, w konsekwencji otrzymywania dotacji podmiotowej i subwencji z budżetu państwa jedynie przez niewielką liczbę partii politycznych ma miejsce przede wszystkim wzmocnienie najsilniejszych z nich i mających reprezentacje parlamentarna, a tym samym utrwalenie (zacementowanie) sceny politycznej. Musi rodzić to pytanie o to, czy rozwiązanie to jest zgodne z konstytucyjną zasadą pluralizmu politycznego, której jednym z najważniejszych elementów jest równość partii politycznych ${ }^{98}$. A. Ławniczak wskazał, że państwowe finansowanie partii

93 A. Ławniczak, Finansowanie partii politycznych, Warszawa 2001, s. 59.

${ }^{44} \mathrm{~J}$. Zaleśny, Finansowanie kampanii wyborczej w wyborach parlamentarnych. Regulacje prawne $i$ ich stosowanie, „Ius Novum” 2011, nr 4, s. 70.

${ }_{95}$ K. Wojtas, Finansowanie partii politycznych w Polsce w latach 2002-2006, "Athenaeum” 2008, nr 19, s. 38.

${ }_{96}$ M. Bidziński, Finansowanie, s. 44-45; K. Skotnicki, Modele i źródła finansowania partii politycznych, „Przegląd Sejmowy” 2014, nr 1, s. 47.

97 T. Gąsior, Problematyka finansowania partii politycznych w Polsce, "Przegląd Sejmowy” 2013, nr 5, s. 30-31.

${ }^{98}$ K. Skotnicki, Finansowanie partii politycznych w Polsce, „Toruńskie Studia Polsko-Włoskie" 2016, t. XII, s. 92. 
powoduje negatywny proces etatyzacji życia politycznego, stanowiący odpowiedź na zagrożenie ustabilizowanych struktur państwowych przez niezależne i chaotycznie działające partie polityczne ${ }^{99}$. Co więcej, w odbiorze społecznym to składki członkowskie traktowane są jako najbardziej prawidłowa, pożądana i demokratyczna forma finansowania partii politycznych ${ }^{100}$, niestety ich znaczenie jest współcześnie znikome, ze względu na niewielką liczbę członków partii oraz niską wysokość składek ${ }^{101}$. Biorąc pod uwagę wspomniane wyżej negatywne konsekwencje obowiązującego systemu, tym większego znaczenia nabiera kwestia transparentności finansów partii politycznych, która związana jest nieodłącznie z prawem do informacji publicznej. Dlatego też w literaturze podkreśla się znaczenie umożliwienia społecznej kontroli zarówno pozyskiwania, jak i wydatkowania środków finansowych ${ }^{102}$.

Zasady gromadzenia środków finansowych wynikają przede wszystkim z konstytucyjnej zasady jawności finansowania partii politycznych ${ }^{103}$. Art. 11 ust. 2 Konstytucji, który mówi, że finansowanie partii politycznych jest jawne, posiada bowiem rangę zasady o najwyższym znaczeniu normatywnym ${ }^{104}$. Treścią tego prawa jest roszczenie, którego „wykorzystanie” ma prowadzić do uzyskania świadczenia, przyjmującego postać otrzymania informacji nie przez każdą jednostkę, ale wyłącznie przez obywatela ${ }^{105}$. Każdy zainteresowany może uzyskać dostęp do informacji związanych z finansowaniem partii czy komitetu wyborczego, co skłania tak partie polityczne, jak i komitety wyborcze do ostrożności i eliminuje przynajmniej część zachowań tak prawnie, jak i społecznie niepożądanych ${ }^{106}$. Bardzo

99 A. Ławniczak, Finansowanie, s. 59.

100 M. Bidziński, Finansowanie partii politycznych w Polsce, Warszawa 2011, s. 86.

101 A. Ławniczak, Finansowanie, s. 47-48.

102 A. Jackowska, J. Zbieranek, Społeczna kontrola finansowania partii politycznych, [w:] J. Zbieranek (red.), Subwencje z budżetu państwa dla partii politycznych. Jawność $i$ kontrola, Warszawa 2008, s. 36-42.

${ }^{103}$ M. Chmaj, Jawność finansowania polityki, [w:] M. Chmaj (red.), Finansowanie polityki w Polsce na tle europejskim, Toruń 2008, s. 35.

104 J. Uliasz, Finansowanie prezydenckiej kampanii wyborczej w 2010 r., [w:] S.J. Jaworski, K.W. Czaplicki (red.), Księga Pamiątkowa z okazji obchodów 20-lecia demokratycznych wyborów w Polsce, Warszawa 2011, s. 200.

${ }^{105}$ K. Wojtyczek, Konstytucyjny status jednostki w państwie polskim, [w:] P. Sarnecki (red.), Prawo konstytucyjne RP, Warszawa 2008, s. 93.

106 J. Zaleśny, Finansowanie parlamentarnej kampanii wyborczej - specyfika polska, [w:] E. Pietrzyk-Zieniewicz (red.), Przed wyborami. Konflikty, strategie, nadzieje, "Studia Politologiczne" 2005, nr 9, s. 147. 
istotnym z punktu widzenia zachowania zasady jawności finansów partyjnych jest nałożony na komitety wyborcze obowiązek gromadzenia środków finansowych wyłącznie na rachunku bankowym ${ }^{107}$, jak również zakaz prowadzenia działalności gospodarczej oraz zbiórek publicznych ${ }^{108}$. Pojęcie "publicznych środków finansowych" należy traktować szeroko, jako wszelkie procesy związane z gromadzeniem środków publicznych oraz ich rozdysponowywaniem ${ }^{109}$.

Biorąc pod uwagę, że sama zasada jawności, jak również szereg rozwiązań dotyczących udostępniania informacji publicznej zostało wprowadzonych w państwach Europy Zachodniej przed ich zastosowaniem w polskim porządku prawnym, można zauważyć, iż na poziomie europejskim partie polityczne finansowane $\mathrm{z}$ budżetu UE powinny co roku publikować swoje dochody i wydatki oraz sporządzać listy darczyńców i darowizn, które przekraczają kwotę 500 euro. Środki otrzymywane z budżetu Unii mogą być przeznaczane wyłącznie na wydatki związane $\mathrm{z}$ realizacją celów partii wyrażonych w programie politycznym, takie jak wydatki administracyjne, wydatki związane z pomocą techniczna, spotkaniami, badaniami, wydarzeniami transgranicznymi, studiami, informacją i publikacjami ${ }^{110}$. W odniesieniu do uregulowań obowiązujących $\mathrm{w}$ innych państwach, przepisy regulujące finansowanie kampanii wyborczych można podzielić na dwie grupy: regulacje koncentrujące się na kontroli sposobu wydawania pieniędzy przez partie (przeznaczenie środków finansowych) oraz dotyczące kontroli wszelkich wpływów finansowych partii (reglamentacja form przychodu) ${ }^{111}$. Tak więc element kontroli wydatków partyjnych pozostaje obecny w wielu współczesnych systemach normatywnych.

$\mathrm{W}$ polskim porządku prawnym, $\mathrm{w}$ związku z rozbieżnościami $\mathrm{w}$ odczytywaniu przepisów UDIP, dotyczącymi tak doktryny, jak i orzecznictwa, udostępnianie informacji o sposobach wydatkowania środków pub-

107 A. Ławniczak, Finansowanie, s. 156.

108 J. Juchniewicz, O potrzebie nowych rozwiazań w zakresie finansowania partii politycznych uwag kilka, „Studia Prawnoustrojowe” 2012, nr 18, s. 46.

109 I. Kamińska, M. Rozbicka-Ostrowska, Ustawa o dostępie do informacji publicznej. Komentarz praktyczny, Warszawa 2008, s. 66.

110 B. Kosowska-Gąstoł, Prawna instytucjonalizacja partii politycznych na poziomie europejskim, „Studia Europejskie” 2005, nr 3, s. 85.

${ }^{111}$ R. Wiszniowski, Marketing wyborczy. Studium kampanii wyborczych w systemach prezydenckich i semiprezydenckich (Finlandia, Francja, Polska, Stany Zjednoczone), WarszawaWrocław 2000, s. 94. 
licznych przez partie polityczne miało przez długi czas charakter bardzo ograniczony. Jeszcze w 2012 r. zauważono, że dostęp do dokumentacji znajdującej się w siedzibach partii politycznych, a związanej z operacjami finansowanymi ze środków pochodzących z subwencji był bardzo utrudniony. Obowiązywała wręcz zasada pełnej uznaniowości działaczy partyjnych co do podmiotów i zakresu, w jakim można się zapoznać z takimi dokumentami ${ }^{112}$. Dlatego też postulowano dokładne uregulowanie tej kwestii i stworzenie jasnych procedur udostępniania dokumentacji - ze szczególnym uwzględnieniem ustawy o ochronie danych osobowych ${ }^{113}$. Zdaniem R. Piotrowskiego zmiany w systemie finansowania partii politycznych powinny polegać przede wszystkim na pełnym i rzeczywistym zrealizowaniu zasady jawności oraz publicznej kontroli nad tym procesem niezależnie od tego, czy chodzi o wydatkowanie środków budżetowych czy też środków pochodzących ze składek i darowizn oraz z innych źródeł ${ }^{114}$.

W orzecznictwie sądów administracyjnych zarysowały się w tej sprawie dwa rozbieżne stanowiska, co więcej, obydwa przejawiły się w wyrokach NSA.

Pierwsze z nich sprowadza się do wykładni art. 23a UPP. Zdaniem składu orzekającego sąd niższej instancji błędnie przyjął, że skoro z wymienionego przepisu wynika, iż źródła finansowania partii politycznych są jawne, to informacja dotycząca ewentualnego finansowania gazety przez partię ma charakter informacji publicznej ${ }^{115}$. Sąd zwrócił uwagę, że czym innym jest finansowanie partii, czym innym zaś wydatkowanie przez partię środków pieniężnych. Wywód NSA sprowadził się w istocie do konkluzji, że przepis stanowiący o jawnym charakterze źródeł finansowania partii politycznych nie dotyczy w ogóle sposobu dysponowania przez partie tymi środkami. Warto jednak zauważyć, że skład orzekający, zarzucając warszawskiemu WSA powierzchowność w badaniu sprawy, sam najwyraźniej popadł $\mathrm{w}$ tę przypadłość. W uchylonym wyroku, po zacytowaniu kilku przepisów UPP (w tym wspomnianego przez NSA

112 M. Gałązka, M. Solon-Lipiński, J. Zbieranek, Przejrzystość finansowania kampanii wyborczych i partii politycznych. Wybrane problemy i rekomendacje, Warszawa 2012, s. 22.

113 Ustawa z dnia 29 sierpnia 1997 r. o ochronie danych osobowych (tekst jedn. Dz. U. z 2016 r. poz. 922).

114 R. Piotrowski, Demokracja a finansowanie partii politycznych w świetle Konstytucji RP, „Studia Iuridica Lublinensia” 2014, nr 22, s. 292.

115 Wyrok Naczelnego Sądu Administracyjnego z 3 października 2014 r., I OSK 429/14, CBOSA. 
art. 23a tej ustawy) została bowiem zawarta analiza, iż dana partia polityczna spełnia funkcje publiczne, a jej udział w życiu publicznym może być realizowany poprzez wydawanie gazet czy biuletynów informacyjnych. Są to zatem sprawy nierozerwalnie związane z domeną publiczna, odnoszą się do funkcjonowania partii w sferze publicznej i przez to stanowią informację publiczną $\mathrm{w}$ rozumieniu art. 1 ust. 1 UDIP ${ }^{116}$. Art. 23a UPP został zatem wspomniany obok innych przepisów tego aktu jako tło prawne badanej sprawy i w żadnym razie nie stanowi samodzielnej podstawy dla końcowej tezy wyroku, jak błędnie odczytał to NSA. Walor informacji publicznej został bowiem przez sąd niższej instancji wyprowadzony z analizy występowania elementu publicznego w badanym zakresie przedmiotowym.

Drugie stanowisko zajęte przez NSA zaledwie miesiąc później jest już całkiem odmienne. Jak zauważył sąd, nie można co prawda utożsamiać źródła finansowania $\mathrm{z}$ wydatkowaniem środków finansowych, jednak z powszechnie obowiązujących regulacji wynika, że także owo wydatkowanie dokonywane przez partie polityczne stanowi informacje publiczną ${ }^{117}$. Przeznaczenie majątku partii politycznej nie jest wyłącznie sprawą wewnętrzną partii, bowiem może on być przeznaczony tylko na cele statutowe lub charytatywne. Skład orzekający zwrócił również uwagę na otrzymywanie przez partie polityczne subwencji z budżetu. Przeznaczenie przez partię środków finansowych uzyskanych z budżetu państwa jest zatem istotne $\mathrm{z}$ punktu widzenia interesu publicznego polegającego na tym, aby majątek publiczny był przeznaczony w sposób zgodny z prawem, tj. na cele określone przez ustawodawcę. Co więcej, także majątek partii politycznej uzyskany z darowizn, spadków i zapisów, nie jest wyłącznie sprawą wewnętrzną partii, w zakresie, w jakim środki finansowe pochodzące $\mathrm{z}$ tych źródeł gromadzone są w ramach Funduszu Wyborczego. Wydatkowanie przez partię środków finansowych należy więc do zakresu spraw publicznych ${ }^{118}$.

Powyższy pogląd został w sposób niezwykle jasny sformułowany w późniejszym orzeczeniu NSA, który stwierdził, że wydatki partii po-

116 Wyrok Wojewódzkiego Sądu Administracyjnego w Warszawie z 6 listopada 2013 r., II SAB/Wa 447/13, CBOSA.

117 Wyrok Naczelnego Sądu Administracyjnego z 26 listopada 2014 r., I OSK 633/14, CBOSA.

118 Tamże. 
litycznej są sprawą publiczna, a informacja na ten temat podlega - co do zasady - udostępnieniu na zasadach i w trybie określonych w UDIP ${ }^{119}$.

Ta linia orzecznicza jest kontynuowana i wzbogacana argumentacyjnie przez warszawski WSA, który stwierdził, że zagadnienie transparentności działania partii politycznych $\mathrm{w}$ zakresie ich finansowania przenosi się wprost na zagadnienie wydatkowania zgromadzonych przez partie środków finansowych ${ }^{120}$. Charakter informacji publicznej posiada każdy dokument obrazujący sposób wydatkowania środków finansowych przez partię polityczną wykonującą funkcje publiczne (komu, ile, za co, na jakich warunkach $)^{121}$.

Judykatura zaczyna więc z biegiem czasu potwierdzać stanowisko, jakie odnaleźć można w literaturze, iż obecność elementu publicznego w sprawach z zakresu wydatkowania środków finansowych przez partie polityczne jest dość silnie zaznaczona ${ }^{122}$.

Inne zagadnienie problemowe dotyczy faktur. W tym zakresie orzecznictwo administracyjne nie pozostawia wątpliwości. Faktury opłacone przez partię polityczną są $\mathrm{w}$ jego świetle dokumentami zawierającymi informację o sprawach publicznych. Tym niemniej partie polityczne nie składają broni i wciąż jeszcze próbują podważać status informacji publicznej w odniesieniu do swoich faktur.

Prekursorem w egzekwowaniu dostępu do informacji publicznej znajdującej się w gestii partii politycznych była Sieć Obywatelska Watchdog ${ }^{123}$, która zwróciła się z żądaniem do pięciu partii politycznych o udostępnienie informacji publicznej $\mathrm{w}$ postaci umów o przeprowadzenie sondaży opinii społecznej oraz wszystkich faktur, jakie zostały przez te partie opłacone w ciągu dwóch pierwszych miesięcy $2013 \mathrm{r}$.

Partie polityczne odmówiły przekazania tych informacji argumentując, że powyższe żądanie nie mieści się w żadnej z kategorii uprawnień wymienionych $\mathrm{w}$ art. 3 ustawy o dostępie do informacji publicznej. Ponad to umowy cywilnoprawne zawierane przez partie polityczne nie mają

119 Wyrok Naczelnego Sądu Administracyjnego z 18 grudnia 2014 r., I OSK 611/14, CBOSA.

${ }^{120}$ Wyrok Wojewódzkiego Sądu Administracyjnego w Warszawie z 30 czerwca 2016 r., II SAB/Wa 164/16; wyrok Wojewódzkiego Sądu Administracyjnego w Warszawie z 20 grudnia 2016 r., II SAB/Wa 437/16; CBOSA.

${ }^{121}$ Wyrok Wojewódzkiego Sądu Administracyjnego w Warszawie z 18 listopada 2015 r., II SAB/Wa 714/15, CBOSA.

${ }^{122}$ W. Jakimowicz, Publiczne prawa podmiotowe, Kraków 2002, s. 251.

${ }^{123}$ siecobywatelska.pl/nieprzejrzsytosc-partyjna/ [dostęp: 9.11.2016 r.]. 
statusu dokumentów urzędowych, podobnie jak faktury i wyniki badań opinii społecznej. Powołano się również na tajemnicę przedsiębiorcy.

Powyższe stanowisko zajęte zgodnie przez największe polskie partie polityczne skutkowało złożeniem skarg na bezczynność do sądu administracyjnego.

Sąd przyznał rację skarżącej, uznając, że faktury są dokumentami zawierającymi informację o sprawach publicznych, tj. informację o wydatkowaniu przez partię polityczną środków finansowych, w tym pochodzących z budżetu państwa ${ }^{124}$. Uczestnictwo partii politycznej w wyborach, rejestracja komitetów wyborczych i kandydatów, potencjalny lub realny wpływ na obsadzenie stanowisk publicznych oraz finansowanie działalności z budżetu państwa sa jak orzekł sąd, przejawami aktywności w sferze publicznej, a informacje na ten temat dotyczą spraw publicznych ${ }^{125}$. Żądana do udostępnienia informacja w postaci faktur opłaconych przez partię polityczną spełnia warunki informacji publicznej, dotyczy bowiem sposobu dysponowania majątkiem przez partię polityczną wykonującą funkcje publiczne ${ }^{126}$.

Inny aspekt związany z wydatkowaniem środków finansowych przez partie polityczne dotyczy kwestii umów zawieranych przez te podmioty na przeprowadzenie badań opinii społecznej. W świetle jednolitego w tym zakresie orzecznictwa sądów administracyjnych umowy takie stanowią informację publiczną.

Powyższy problem stał się przedmiotem sporów sądowych pomiędzy partiami politycznymi a wspomnianym wcześniej stowarzyszeniem. Partia posłużyła się w swojej argumentacji trzema podstawowymi twierdzeniami. Po pierwsze, jej zdaniem treść umów zawartych przez nią z podmiotami prywatnymi w żadnym wypadku nie jest "sprawą publiczną". Badania opinii społecznej są opłacane przez partie ze środków własnych, zaś formułowane na ich podstawie raporty stanowią przedmiot praw majątkowych partii i brak jest uzasadnienia dla żądania, aby te dobra intelektualne wchodziły do domeny publicznej. Badania opłacone w całości przez partię nie powinny być powierzane podmiotom trzecim, takim jak

${ }^{124}$ Wyrok Wojewódzkiego Sądu Administracyjnego w Warszawie z 15 listopada 2013 r., II SAB/Wa 408/13, CBOSA.

125 Tamże.

126 Wyrok Wojewódzkiego Sądu Administracyjnego w Warszawie z 28 stycznia 2014 r., II SAB/Wa 420/13; wyrok Wojewódzkiego Sądu Administracyjnego w Warszawie z 2 kwietnia 2014 r., II SAB/Wa 757/13; CBOSA. 
stowarzyszenia, czy też szerszej publiczności ${ }^{127}$. Po drugie, w stosunku do partii politycznych jako podmiotów innych niż władze publiczne i osoby pełniące funkcje publiczne charakter informacji publicznej należy przypisać jedynie tym, które odnoszą się do wskazanej w art. 61 Konstytucji RP publicznej sfery ich działalności, a więc wykonywania zadań władzy publicznej i gospodarowania mieniem komunalnym lub majątkiem Skarbu Państwa. Co za tym idzie, w zakresie, w jakim partie nie dysponują majątkiem państwowym bądź komunalnym, podejmowane przez nie działania nie stanowią „spraw publicznych". Partie polityczne nie wykonują również zadań publicznych ${ }^{128}$. Po trzecie, w odpowiedzi na skargę znalazło się oskarżenie wnioskodawcy o zamiar przejęcia wartości majątkowych i intelektualnych opłaconych przez partię polityczna, co miało być istotą złożonego przez stowarzyszenie wniosku o dostęp do informacji publicznej. Po czwarte, partia podniosła kwestię klauzul poufności, jakie znajdują się często w umowach dotyczących badań opinii społecznej, zawieranych $\mathrm{z}$ instytutami badawczymi.

Zdaniem sądu, argument dotyczący sfery finansowej jest nietrafny wobec brzmienia art. 11 ust. 2 Konstytucji RP oraz art. 23a UPP, z których wynika zasada jawności finansowania partii politycznych. Zasada ta oznacza z kolei zakaz utajniania finansów partyjnych oraz odpowiadający mu nakaz ujawniania informacji finansowych o działalności partii, w tym wszelkich informacji związanych ze źródłami i sposobami gromadzenia środków finansowych oraz wskazywania celów i podstaw ich wydatkowania $^{129}$. Sąd postrzega jawność finansowania działalności partyjnej jako instrument zwalczania korupcji i innych negatywnych zjawisk, stwarzających zagrożenia dla stabilności politycznej państwa i demokratycznej gry wyborczej. Jak trafnie zauważono w orzeczeniu, biorąc pod uwagę podstawy działania partii politycznych należy uznać za słuszne i pożądane, aby obywatele mieli dostęp do informacji dotyczących finansów partii politycznych. Wynika to szczególnie z okoliczności, że zasoby pieniężne poszczególnych ugrupowań, a zwłaszcza partii wchodzących do parlamentu składają się w znacznej mierze ze środków publicznych (subwencji lub dotacji, kreowanych m.in. z wpływów podatkowych) ${ }^{130}$. Skoro więc

${ }^{127}$ Wyrok Wojewódzkiego Sądu Administracyjnego w Warszawie z 21 listopada 2013 r., I SAB/Wa 416/13, CBOSA.

128 Tamże.

129 Tamże.

130 Tamże. 
obywatele, co najmniej pośrednio, jako podatnicy uczestniczą w finansowaniu partii politycznych, powinni mieć zatem prawo do weryfikacji źródeł i sposobów gromadzenia oraz wydatkowania pieniędzy przez te podmioty.

NSA zgodził się z sądem I instancji, że umowy zawarte przez partię polityczna, w tym umowy dotyczące badań opinii publicznej zawierają informację publiczną, obrazują bowiem sposób, w jaki partia wydatkuje środki finansowe ${ }^{131}$. Wyniki tych badań są zaś z kolei dowodem wykonania umów i w tym znaczeniu zawierają informacje o wydatkowaniu środków finansowych, szczególnie o ich prawidłowości. Jeżeli bowiem zakres analiz jest niewspółmierny do kwot określonych w umowach, to informacja taka ma istotne znaczenie z punktu widzenia wydatkowania ${ }^{132}$.

Jak zauważył NSA, fakt, że majątek partii politycznej może pochodzić z różnych źródeł - zarówno publicznych, jak i prywatnych - nie oznacza, iż sposób dysponowania tym majątkiem nie stanowi sprawy publicznej. Może on bowiem być przeznaczony tylko na cele statutowe lub charytatywne. Skoro więc podstawowym celem każdej partii politycznej jest udział w życiu publicznym poprzez wywieranie metodami demokratycznymi wpływu na kształtowanie polityki państwa lub sprawowanie władzy publicznej, to niezależnie od źródła pochodzenia środków finansowych, sposób ich wydatkowania stanowi sprawę publiczną ${ }^{133}$.

Status informacji publicznej został również uznany w judykaturze w odniesieniu do umów cywilnoprawnych zawieranych przez partie polityczne.

O ile w powyższym kazusie sądy zajmowały się szczególnym rodzajem umów, a mianowicie dotyczących przeprowadzenia badań opinii społecznej, co miało też wpływ na dobór i kształt argumentów podnoszonych przez strony oraz sformułowanych przez sąd w orzeczeniu - o tyle jeden $\mathrm{z}$ najnowszych wyroków w przedmiocie udostępniania informacji publicznej przez partie polityczne dotyczy umów cywilnoprawnych w ogólności. Rzecz jasna, informacja żądana do udostępnienia miała charakter konkretny i dotyczyła umów zawartych przez partię z jednym $\mathrm{z}$ adwokatów. Rozstrzygnięcie sprawy wymagało jednak odniesienia się

131 Wyrok Naczelnego Sądu Administracyjnego z 18 grudnia 2014 r., I OSK 611/14, CBOSA.

132 Tamże.

133 Tamże. 
do problematyki udostępniania informacji o umowach cywilnoprawnych jako takich.

Partia powołała się w swojej argumentacji na konstytucyjną wolność działania partii politycznych, w której kontekście postrzega ustawową jawność funkcjonowania partii ograniczoną do następujących obszarów: źródeł finansowania, struktur partyjnych i zasad działania oraz ewidencji i statutów. Zdaniem partii nie wykonuje ona funkcji publicznych, bowiem nie sprawuje władzy publicznej ani nie wykonuje zadań publicznych, tym samym nie dotyczy jej generalna zasada jawności. Ponadto umowy cywilnoprawne nie posiadają przymiotu sprawy publicznej i nie są dokumentem urzędowym.

Sąd nie podzielił tej argumentacji. Skoro działalność partii politycznych, w tym zwłaszcza dotacje budżetowe, może stanowić przedmiot informacji publicznej, tym samym żądana informacja w zakresie umów cywilnoprawnych spełnia warunki informacji publicznej, dotyczy bowiem działania partii politycznej wykonującej funkcje publiczne, co więcej, jest to partia parlamentarna ${ }^{134}$. UDIP zdaniem sądu w sposób bardzo szeroki kształtuje zakres pojęcia informacji publicznej, a zatem mieszczą się w nim także dokumenty prywatne, jakim są umowy. Obrazują one bowiem cel, na który dana partia wydaje określone środki finansowe.

W tym kontekście powołać można pogląd wyrażony w najnowszej literaturze, że od kiedy uchwalono UDIP, to judykatura decyduje, jak duża może być przejrzystość administracji publicznej. Według A. Zdunka trudno oprzeć się wrażeniu, że o ile organy administracji najniższego szczebla zobowiązane są przez orzecznictwo do udzielania informacji publicznej dotyczących danych osobowych osób, które zawierały z organami administracji publicznej umowy cywilnoprawne - o tyle im ważniejszy w hierarchii jest organ, który zobowiązany jest do udzielenia odpowiedzi, tym wyroki sądów są odmienne i wyłamują się z ugruntowanego przez judykaturę stanowiska ${ }^{135}$. Abstrahując od oceny trafności tego poglądu, która wymagałaby oddzielnej analizy stosownego orzecznictwa, warto jednak docenić konsekwencję, z jaką sądy administracyjne uznają charakter informacji publicznej w odniesieniu do umów cywilnoprawnych zawieranych przez partie polityczne.

${ }^{134}$ Wyrok Wojewódzkiego Sądu Administracyjnego w Warszawie z 30 czerwca 2016 r., II SAB/Wa 164/16, CBOSA.

135 A. Zdunek, Ograniczenie prawa do informacji publicznej w orzecznictwie sadów administracyjnych - wybrane zagadnienia, „Rocznik Administracji Publicznej” 2016, nr 2, s. 93-94. 
Zagadnieniem, które nie zostało jednoznacznie rozstrzygnięte w orzecznictwie jest kwestia, czy wyniki badań opinii społecznej są informacją publiczną.

Warszawski WSA udzielił w tym zakresie odpowiedzi twierdzącej. Sąd powołał się na fakt znany z urzędu, że partie polityczne bardzo często odnoszą się do wyników badania opinii publicznej. Taka powszechna praktyka nakazuje zaliczyć wyniki tych badań do zbioru informacji publicznych. Ponadto, jak zauważył WSA, badania takie odnoszą się wprost do społeczeństwa, opisu jakiegoś aspektu jego poglądów czy ocen - zatem zawierają $\mathrm{w}$ sobie element publiczny ${ }^{136}$. W innej sprawie sąd uznał, że umowy, jakie zostały podpisane w celu przeprowadzenia na zlecenie partii badań opinii społecznej oraz ich wyniki są dokumentami zawierającymi informację o sprawach publicznych, tj. informację o wydatkowaniu przez partię polityczną środków finansowych, w tym pochodzących z budżetu państwa. Wyniki tych badań są zdaniem sądu nierozerwalnie związane z przedmiotowymi umowami, są bowiem dowodem, że umowy zostały przez zleceniobiorcę wykonane ${ }^{137}$.

NSA uznał jednak, że wyniki badań opinii społecznej zamówionych przez partię polityczną nie stanowią informacji o wydatkowaniu środków finansowych. Przeznaczenie środków finansowych na określony cel oraz wysokość poniesionego wydatku wynikają bowiem z umowy, a zatem dostęp do tych danych można uzyskać poprzez dostęp do umowy. Wyniki przeprowadzonych badań nie są danymi o przeznaczeniu środków oraz wysokości wydatku. Mogłyby one być uznane za informację publiczna, gdyby dotyczyły wykonywania przez zobowiązany podmiot zadań publicznych ${ }^{138}$. Zdaniem sądu publiczne udostępnianie ocen, ekspertyz czy też wyników badań opinii społecznej ograniczałoby partię w jej działaniach zmierzających do realizacji celu godziłoby w konstytucyjną wolność działania, o której mowa w art. 11 ust. 1 zdanie 1 Konstytucji RP. Uznanie informacji o metodach i środkach działania partii za informację publiczną byłoby wpływaniem państwa na jej działalność i prowadziłoby do niczym nieusprawiedliwionego korzystania innych uczestników systemu poli-

${ }^{136}$ Wyrok Wojewódzkiego Sądu Administracyjnego w Warszawie z 21 listopada 2013 r., I SAB/Wa 416/13, CBOSA.

137 Wyrok Wojewódzkiego Sądu Administracyjnego w Warszawie z 15 listopada 2013 r., II SAB/Wa 409/13, CBOSA.

${ }^{138}$ Wyrok Naczelnego Sądu Administracyjnego z 26 listopada 2014 r., I OSK 633/14, CBOSA. 
tycznego z dorobku partii politycznej. Stanowiłoby to zaprzeczenie pluralizmu, tzn. wolnego konkurowania idei, programów i interesów. Dlatego też należy uznać, że dane uzyskane w wyniku badań opinii społecznej są danymi wewnętrznymi partii politycznej ${ }^{139}$.

Przeciwne stanowisko znalazło się jednak w orzeczeniu wydanym przez inny skład orzekający NSA. Podzielił on argumentację sądu niższej instancji, że wyniki badań opinii społecznej przeprowadzonych na zlecenie partii politycznej są dowodem wykonania umów i w tym znaczeniu zawierają informacje o wydatkowaniu środków finansowych ${ }^{140}$. Powołując się na doktrynę sąd skonstatował, że uczestnictwo w wyborach, rejestracja komitetów wyborczych i kandydatów, wpływ na obsadzanie stanowisk publicznych, finansowanie z budżetu państwa są ewidentnymi dowodami aktywności partii politycznych w sferze publicznej. Różnego rodzaju badania, opinie i ekspertyzy są często wykorzystywane przez partie polityczne w ich działalności publicznej, zaś nad częścią z nich toczy się debata publiczna. Ich wykorzystanie może wywierać wpływ na sprawy publiczne i decydować o wydatkowaniu środków publicznych. Jak skonkludował NSA, informację o szeroko rozumianych sprawach publicznych zawierać więc mogą sondaże i opinie, nawet te, które nie weszły do debaty publicznej, gdyż nie zostały ujawnione ${ }^{141}$.

Trzeba w tym miejscu zauważyć, że badania opinii społecznej zamawiane przez partie polityczne przy założeniu poufności wyników mogą odnosić się do różnych kwestii. Niekoniecznie mogą to być jedynie typowe badania preferencji partyjnych, nieróżniące się zakresem i metodologią od jawnych badań szeroko komentowanych w środkach masowego przekazu. Partie polityczne mogą przecież zlecić instytutom badania opinii przeprowadzenie sondażu dotyczącego społecznego odbioru konkretnych polityków danej partii, a nawet wygłoszonych przez nich publicznie określonych poglądów. Uzyskane w ten sposób informacje mogą pomóc w kształtowaniu polityki personalnej i programowej partii politycznej i jako takie stanowią jej wewnętrzną sprawę. Ujawnienie wyników takich badań może powodować negatywne konsekwencje polityczne i utratę poparcia społecznego. Partia zlecić może również badanie opinii publicznej pod względem swoich przyszłych planów i zamierzeń, sondując nastro-

139 Tamże.

140 Wyrok Naczelnego Sądu Administracyjnego z 18 grudnia 2014 r., I OSK 611/14, CBOSA.

141 Tamże. 
je społeczne w określonych sprawach. Upublicznienie wyników takiego sondażu stanowiłoby wówczas cenną informację dla konkurencyjnych partii politycznych $\mathrm{w}$ zakresie projektowanych kierunków działania danej partii. Co więcej, fakt zlecenia takiego sondażu mógłby wówczas niezgodnie z prawdą zostać propagandowo przedstawiony jako potwierdzenie, że dana partia zamierza w przyszłości przeprowadzić niepopularne społecznie działania - podczas gdy w rzeczywistości wspomniany sondaż mógł posłużyć przeciwnemu celowi w postaci ich uniknięcia.

\section{Element wewnętrzny $w$ działalności partii politycznych}

Orzecznictwo w sprawach dotyczących partii politycznych zawiera przypomnienie definicji dokumentu urzędowego mającego zastosowanie na gruncie UDIP. Jedna z partii obstawała bowiem przy zastosowaniu definicji tegoż dokumentu znajdującej się w art. 244 § 1 Kodeksu postępowania cywilnego ${ }^{142}$. Zgodnie $\mathrm{z}$ tą definicją dokumenty urzędowe, sporządzone $\mathrm{w}$ przepisanej formie przez powołane do tego organy władzy publicznej i inne organy państwowe w zakresie ich działania, stanowią dowód tego, co zostało w nich urzędowo zaświadczone. Sąd administracyjny skorygował ten pogląd, odwołując się do art. 6 ust. 2 UDIP, zgodnie $\mathrm{z}$ którym dokumentem urzędowym $\mathrm{w}$ rozumieniu ustawy jest treść oświadczenia woli lub wiedzy, utrwalona i podpisana w dowolnej formie przez funkcjonariusza publicznego w rozumieniu Kodeksu karnego ${ }^{143}$, w ramach jego kompetencji, skierowana do innego podmiotu lub złożona do akt sprawy ${ }^{144}$.

Pogląd powszechnie przyjęty zarówno w orzecznictwie, jak też i w doktrynie traktuje pojęcie informacji publicznej z UDIP jako znacznie szersze niż dokument urzędowy ${ }^{145}$. Jest to m.in. treść dokumentów wytworzonych przez organy władzy publicznej, treść wystąpień i ocen

142 Ustawa z dnia 17 listopada 1964 r. - Kodeks postępowania cywilnego (tekst jedn. Dz. U. z 2016 r. poz. 1822 z późn. zm.).

143 Ustawa z dnia 6 czerwca 1997 r. - Kodeks karny (Dz. U. Nr 88, poz. 553 z późn. zm.).

${ }^{144}$ Wyrok Wojewódzkiego Sądu Administracyjnego w Warszawie z 15 listopada 2013 r., II SAB/Wa 408/13, CBOSA.

${ }^{145}$ B. Dolnicki, R. Cybulska, Realizacja zasady jawności i dostępu, s. 13-14. 
dokonywanych przez te organy, niezależnie od tego, do kogo są kierowane i jakiej sprawy dotyczą. Są to dokumenty bezpośrednio wytworzone przez organ oraz te, których używa on przy realizacji zadań, w tym nawet te, które tylko w części dotyczą organu, a które mogą także pochodzić od innych podmiotów lub osób prywatnych ${ }^{146}$.

Niejako na marginesie warto zauważyć, że zdaniem części przedstawicieli doktryny informację publiczną należy postrzegać w kontekście wykraczającym poza jej nośnik materialny. Według M. Jabłońskiego mamy do czynienia ze skomplikowanym i złożonym systemem źródeł informacji publicznej obejmującym nie tylko istniejącą $\mathrm{w}$ danym momencie postać sformalizowanych i utrwalonych źródeł informacji, ale i sumę zdarzeń, które mogą zostać pozytywnie zweryfikowane, np. oświadczenie funkcjonariusza publicznego ${ }^{147}$. Dominujący pogląd, którego wyrazicielem jest M. Bernaczyk, nie uznaje jednak roli człowieka jako „nośnika” informacji publicznej, albowiem obiektywna weryfikacja przesłanki „posiadania informacji” jest możliwa tylko w odniesieniu do informacji zmaterializowanej na stosownym nośniku ${ }^{148}$. Podobnie A. Sarota zauważa, że samo pojęcie „informacja” w oderwaniu od jej utrwalonego nośnika powoduje, że niekiedy nie można nawet ustalić, czy taka informacja w ogóle istnieje, a nawet jeśli istnieje, problematyczna staje się jej prawdziwość ${ }^{149}$.

Innym problemem, który został rozpoznany w judykaturze jest status uchwał podjętych przez zarząd partii jako informacji publicznej.

Jak wynika z orzecznictwa, uchwały zarządu partii stanowią formalną podstawę aktywności partii w sferze publicznej - zarówno o znaczeniu lokalnym, jak i ogólnokrajowym, a ponadto dotyczą spraw publicznych ${ }^{150}$. Sąd wymienił w szczególności uchwałę w sprawie zawiadomienia Państwowej Komisji Wyborczej (PKW) o utworzeniu komitetu wyborczego oraz zamiarze zgłoszenia kandydatów w wyborach do Parlamentu Europejskiego, uchwałę w sprawie akceptacji list kandydatów partii w wyborach do PE wraz z listą kandydatów stanowiącą załącznik do uchwały, uchwałę w sprawie zawiadomienia PKW o utworzeniu komitetu wybor-

146 M. Jabłoński, Udostępnianie informacji w trybie wnioskowym, Wrocław 2009, s. 138.

147 Tenże, Udostępnianie informacji publicznej w formie, s. 145.

148 M. Bernaczyk, Prawo do informacji publicznej, s. 52-53.

149 A. Sarota, Granice dostępności informacji publicznej, „Kontrola Państwowa” 2012, nr 6, s. 55.

${ }^{150}$ Wyrok Wojewódzkiego Sądu Administracyjnego w Warszawie z 5 lutego 2015 r., II SAB/Wa 661/14, CBOSA. 
czego oraz zamiarze zgłoszenia kandydatów na senatora w wyborach uzupełniających, uchwały w sprawie akceptacji kandydatów w wyborach uzupełniających do Senatu RP w określonych okręgach wyborczych ${ }^{151}$. Skoro zatem przyjmuje się, że partia polityczna spełnia funkcje publiczne, to informacje zawarte w uchwałach zarządu dotyczące udziału tej partii w wyborach czy też rejestracji komitetów wyborczych i kandydatów są zdaniem sądu informacją publiczną w rozumieniu art. 1 ust. 1 UDIP.

Jak orzekł sąd, nie przesądza to co do obowiązku udostępnienia wszystkich żądanych informacji, a więc wszystkich uchwał zarządu partii podjętych we wskazanym okresie, lecz przesądza co do obowiązku procedowania przez partię nad powyższym wnioskiem w trybie ustawy o dostępie do informacji publicznej, przy zastosowaniu dostępnych w niej instytucji prawnych ${ }^{152}$.

Rozpatrując sprawę dotyczącą udostępnienia uchwał i protokołów zarządu oraz komisji rewizyjnej jednej z partii politycznych, warszawski sąd administracyjny zaprezentował rozbudowany wywód odnoszący się do generalnego wymogu jawności działania struktur partii politycznych.

Zdaniem sądu nie należy dokonywać sztucznego podziału definicji „informacja publiczna” z art. 1 UDIP na informację podlegającą udostępnieniu przez podmioty wskazane w art. 4 ust. 1 i na informację podlegającą udostępnieniu przez podmioty wskazane w art. 4 ust. $2^{153}$. Takie rozróżnienie pozostawałoby w sprzeczności z generalnym kryterium przyjętym w tej definicji, odnoszącej się do pojęcia - „sprawa publiczna” i z potrzebą jednakowego potraktowania obu powyższych kategorii podmiotów, wskazanym w treści art. 4 ust. 3 UDIP. W tym ujęciu każda informacja spełniająca kryterium przedmiotowe UDIP będzie informacją $\mathrm{w}$ sprawach publicznych. W prawie polskim brak jest bowiem innej definicji informacji publicznej niż wskazana w powyższym przepisie, dlatego też łatwiej jest określać zbiór „informacja publiczna” poprzez negatywne określenie, co do tego zbioru nie należy ${ }^{154}$.

Na początku drugiej części wywodu sąd powtórzył tezę znaną z orzecznictwa administracyjnego, że partia polityczna spełnia funkcje publiczne. Następnie powołał się na art. $8 \mathrm{UPP}$, zgodnie z którym partie

151 Tamże.

152 Tamże.

153 Wyrok Wojewódzkiego Sądu Administracyjnego w Warszawie z 12 stycznia 2015 r., II SAB/Wa 855/14, CBOSA.

154 Tamże. 
polityczne zapewniają jawność swoich struktur, które muszą być ukształtowane zgodnie z zasadami demokracji. Jak zauważono, w UPP brak jest jakiegokolwiek przepisu odwołującego się do zasad tajności, czy niejawności działania partii.

Skoro zatem działalność struktur partii politycznych musi być jawna, zaś zarząd danej partii, jak i jej komisja rewizyjna są to niewątpliwie podmioty należące do struktury danej partii, to ich działania muszą spełniać kryteria zawarte w UPP. Udokumentowanymi wytworami działań tych podmiotów są protokoły z posiedzeń i podjęte uchwały zarządu partii oraz protokoły z posiedzeń komisji rewizyjnej. Zdaniem sądu, jeżeli działania partii dotyczą sfery publicznej, to dokumenty wytworzone w wyniku takich działań stanowią przedmiot informacji publicznej w rozumieniu UDIP ${ }^{155}$.

Powyższe nie przesądza jednak o obowiązku udostępniania przez partie polityczne wszystkich żądanych protokołów i uchwał, przesądza natomiast co do obowiązku procedowania przez partię nad takim wnioskiem $\mathrm{w}$ trybie UDIP, przy zastosowaniu dostępnych $\mathrm{w}$ niej instytucji prawnych.

W odniesieniu do tej konstatacji orzeczniczej można przywołać inny kazus dotyczący partii politycznych, w którym uznano, że protokoły posiedzeń zarządu partii politycznej oraz komisji rewizyjnej, zredagowane w sposób ogólny, nie zawierają informacji publicznej.

Sąd administracyjny przeanalizował dokumentację, którą partia polityczna dostarczyła na jego wezwanie. Jak zauważył skład orzekający, protokoły posiedzeń zarządu partii mają postać zestandaryzowaną co do formy i treści. Zawierają bardzo ogólne informacje dotyczące przebiegu poszczególnych posiedzeń Komitetu Politycznego partii, tj. o otwarciu posiedzenia, zaakceptowaniu protokołu z poprzedniego posiedzenia Komitetu Politycznego, zaproponowaniu porządku obrad, odbyciu dyskusji nad punktami przyjętego porządku obrad oraz o zakończeniu posiedzenia. Nie można więc uznać, że treść tych dokumentów posiada walor informacji publicznej, ponieważ dotyczą one w istocie wewnętrznej organizacji i przebiegu bieżącej pracy partii, a nie „sprawy publicznej”. Ani treść protokołów posiedzeń, ani treść porządków obrad stanowiących 
załączniki do protokołów, zredagowanych również w sposób ogólny, nie zawierają informacji publicznej ${ }^{156}$.

Tego waloru nie posiadają także protokoły z posiedzeń Krajowej Komisji Rewizyjnej, jak również jej uchwała.

W tym kontekście warto przywołać rozważania zawarte w literaturze przedmiotu $\mathrm{w}$ zakresie tzw. dokumentu wewnętrznego. W art. 6 UDIP został wskazany typowy zakres informacji publicznej, który doprecyzowuje zakres przedmiotowy UDIP oraz stanowi wykładnię jej przepisów w kontekście regulacji art. 61 Konstytucji RP, której jest równocześnie rozwinięciem ${ }^{157}$. W doktrynie ${ }^{158}$ i orzecznictwie ${ }^{159}$ spotkać się można z poglądem, że o zakwalifikowaniu określonej informacji do podlegającej udostępnieniu w rozumieniu UDIP będzie decydować kryterium rzeczowe, czyli treść i charakter informacji.

Problematyka dokumentu wewnętrznego była przedmiotem oceny Trybunału, który stwierdził, że przedmiotem konstytucyjnego prawa nie są treści zawarte $\mathrm{w}$ dokumentach wewnętrznych, rozumiane jako informacje o charakterze roboczym (zapiski, notatki), które zostały utrwalone $\mathrm{w}$ formie tradycyjnej lub elektronicznej i stanowią pewien proces myślowy, proces rozważań, etap wypracowywania finalnej koncepcji, przyjęcia ostatecznego stanowiska przez pojedynczego pracownika lub zespół. W ich przypadku można bowiem mówić o pewnym stadium na drodze do wytworzenia informacji publicznej. Od "dokumentów urzędowych" w rozumieniu art. 6 ust. 2 UDIP odróżnia się zatem „dokumenty wewnętrzne" służące wprawdzie realizacji jakiegoś zadania publicznego, ale nieprzesądzające o kierunkach działania organu. Dokumenty takie służą wymianie informacji, zgromadzeniu niezbędnych materiałów, uzgadnianiu poglądów i stanowisk ${ }^{160}$.

M. Jabłoński wyróżnił kilka wariantów będących konsekwencją tak zarysowanego stanowiska Trybunału. W pierwszym z nich należy jego zdaniem zdecydowanie optować za odróżnieniem prawa wglądu do do-

${ }^{156}$ Wyrok Wojewódzkiego Sądu Administracyjnego w Warszawie z 5 lutego 2015 r., II SAB/Wa 661/14, CBOSA.

${ }_{157}$ M. Jabłoński, Wejście w życie ustawy o dostępie do informacji publicznych, „Acta Universitatis Wratislaviensis. Przegląd Prawa i Administracji" 2002, s. 229-230.

158 M. Dalka-Noga, Biuletyn Informacji Publicznej jako forma dostępu do informacji publicznej, „Studia Iuridica Toruniensia” 2013, t. XIII, s. 22.

159 Wyrok Naczelnego Sądu Administracyjnego z 29 lutego 2012 r., I OSK 2215/11, CBOSA.

160 Wyrok Trybunału Konstytucyjnego z 13 listopada 2013 r., P 25/12. 
kumentów urzędowych od prawa wglądu do sumy wszystkich dokumentów, a w zasadzie dostępu do każdej utrwalonej informacji związanej z działalnością zobowiązanego ${ }^{161}$. Takie założenie doprowadziłoby najprawdopodobniej do praktyki nieutrwalania czynności o charakterze roboczym, analitycznym, wstępnie opiniującym, wariantowym, technicznym czy nawet organizacyjnym. Mając na względzie konieczność zapewnienia sprawnego funkcjonowania szerokiej kategorii zobowiązanych, trzeba jednocześnie wziąć pod uwagę, że każdy z piastunów takiego organu (podmiotu) musi dysponować pewną sferą wolną od permanentnie sprawowanej kontroli, która w przypadku UDIP przybiera postać kontroli społecznej ${ }^{162}$.

W drugim wariancie przyjęcie konstrukcji tzw. „dokumentu wewnętrznego" pozwalającego na zakwalifikowanie określonego zbioru informacji jako niepublicznych $\mathrm{w}$ rozumieniu UDIP stwarza pewne wątpliwości interpretacyjne. Prowadzi to bowiem do sytuacji, w której zobowiązany do udostępnienia informacji publicznej może wskazać, że informacje takie nie są informacjami publicznymi, a więc skutecznie wyłączyć możliwość realizacji konstytucyjnego prawa nie tylko w zakresie wglądu do tego rodzaju dokumentów, ale w ogóle dostępu do informacji z takiego dokumentu lub informacji o takim dokumencie ${ }^{163}$.

$W$ trzecim wariancie należy zakwestionować pozaustawową koncepcję „,dokumentu wewnętrznego", zakładając prokonstytucyjną wykładnię prawa dostępu do informacji publicznej, w myśl której z treści art. 61 ust. 1 i 2 Konstytucji wynika prawo wglądu do wszystkich dokumentów znajdujących się $\mathrm{w}$ posiadaniu zobowiązanego do udostępnienia informacji publicznej ${ }^{164}$.

W okresie wcześniejszym, sprzed omawianego wyroku TK, sytuacja dotycząca rozumienia dokumentu wewnętrznego w kontekście udostępniania informacji publicznej pozostawała jeszcze bardziej niejasna, do tego stopnia, iż M. Jabłoński uznawał praktykę udostępniania dokumentów

161 M. Jabłoński, „Dokument wewnętrzny” i jego udostępnienie na podstawie Konstytucji RP oraz ustawy o dostępie do informacji publicznej, [w:] M. Jabłoński, S. Jarosz-Żukowska (red.), Aktualne wyzwania ochrony wolności i praw jednostki. Prace uczniów i wspótpracowników dedykowane Profesorowi Bogusławowi Banaszakowi, Wrocław 2014, s. 92.

162 Tamże, s. 93.

163 Tamże, s. 93-94.

${ }_{164}$ M. Bernaczyk, Funkcja prawa do informacji w polskim porzadku prawnym, [w:] M. Jabłoński (red.), Realizacja i ochrona konstytucyjnych wolności i praw jednostki w polskim porzadku prawnym, Wrocław 2014, s. 388-389. 
innych niż urzędowe za sprzeczną z ustawa, a przez to sprzeczną z konstytucyjną zasadą legalności ${ }^{165}$. Z kolei E. Jarzęcka-Siwik uznała, że tzw. dokumenty wewnętrzne, wytworzone w zakresie działania danego podmiotu i wyrażające opinie w sprawach szczegółowych, poglądy przedstawiane $\mathrm{w}$ toku narad albo dyskusji, a także porady udzielane $\mathrm{w}$ ramach konsultacji - nie podlegają udostępnianiu, o ile nie zostały włączone do akt sprawy albo nie zostały wyekspediowane do innego podmiotu. Tym innym podmiotem nie może być przy tym komórka organizacyjna podmiotu zobowiązanego do udostępnienia informacji, gdyż w ten sposób obowiązek informacyjny należałoby rozciągnąć także na zgłaszanie pewnych pomysłów co do załatwienia sprawy albo nawet na wymianę poglądów za pomocą poczty elektronicznej lub rozmów telefonicznych ${ }^{166}$.

Omówione powyżej orzeczenia, oprócz problematyki dokumentu wewnętrznego, dotykają także kwestii jawności struktur partii politycznej. Wynika ona nie tylko z regulacji ustawowej przywołanej przez sąd, lecz przede wszystkim z art. 13 Konstytucji, zgodnie z którym zakazane jest istnienie partii politycznych i innych organizacji, których program lub działalność przewiduje utajnienie struktur lub członkostwa. Przepis ten należy rozpatrywać w kontekście art. 11 Konstytucji, który stanowi, że partie są tworzone w celu wpływania metodami demokratycznymi na kształtowanie polityki państwa. W ujęciu węższym wspomniane metody demokratyczne dotyczą działalności partii politycznej na zewnątrz. Natomiast w ujęciu szerszym muszą one dotyczyć także wewnętrznej sfery funkcjonowania partii politycznych ${ }^{167}$, wykluczając powstawanie partii typu wodzowskiego, w których najważniejsze organy partyjne nie są wyłaniane $\mathrm{w}$ drodze wyborów ${ }^{168}$.

Wyważone stanowisko w tym zakresie zajął Trybunał Konstytucyjny stwierdzając, że niedemokratyczne elementy wewnątrzorganizacyjne nie

165 M. Jabłoński, Realizacja prawa dostępu do informacji publicznej poprzez wglad do dokumentu, [w:] B. Banaszak, M. Jabłoński, S. Jarosz-Żukowska (red.), Prawo w stużbie państwu i społeczeństwu. Prace dedykowane Profesorowi Kazimierzowi Działosze z okazji osiemdziesiatych urodzin, Wrocław 2012, s. 80.

166 E. Jarzęcka-Siwik, Dostęp do informacji publicznej (uwagi krytyczne), „Kontrola Państwowa" 2002, nr 1, s. 24-42.

167 J. Sobczak, Konstytucyjna wolność tworzenia partii politycznych w Polsce, [w:] M. Granat, P. Policastro, J. Sobczak (red.), Partie polityczne we wspótczesnym konstytucjonalizmie, Lublin 2001, s. 192.

168 P. Uziębło, Aspekty ustrojowe stosunków wewnatrzpartyjnych, „Toruńskie Studia Polsko-Włoskie" 2016, t. XII, s. 109. 
zawsze muszą mieć bezpośredni i istotny wpływ na wypełnianie przez partię jej roli ustrojowej lub stosowane przez nią zewnętrzne metody działania. W związku z tym swoboda kształtowania wewnętrznych struktur i zasad funkcjonowania partii nie może być ograniczana, jak długo nie zagraża wypełnianiu przez partię jej konstytucyjnej roli lub jak długo nie wyklucza demokratyczności metod, jakimi partia zamierza wpływać. Jak jednak zauważył TK, brak demokracji wewnątrzorganizacyjnej musi być brany pod uwagę przy orzekaniu o zgodności z Konstytucją celów lub działalności partii politycznych, jeżeli uniemożliwia lub choćby tylko $\mathrm{w}$ istotny sposób ogranicza spełnianie przez partię jej konstytucyjnej roli lub przekłada się bezpośrednio na zakładane lub stosowane przez nią metody kształtowania polityki państwa ${ }^{169}$.

Interesujący problem, który pojawił się w orzecznictwie dotyczy tego, czy przyczyny i zasady umieszczania logo partii politycznej na wydawnictwach oraz finansowanie przez partię ich publikacji stanowi informację publiczną.

Wniosek o udostępnienie informacji publicznej przez partię polityczną został w tej sprawie skierowany nie przez stowarzyszenie obywatelskie, jak miało to miejsce w innych przypadkach, lecz przez wójta pewnej gminy. Żądał on udostępnienia informacji, czy partia ta w jakikolwiek sposób uczestniczy w wydawaniu gazety gminnej, wydawanej przez jednego z radnych. Pytania skierowane przez włodarza gminy dotyczyły tego, czy wspomniany periodyk jest finansowany z funduszy owej partii, a jeśli tak, to na jakich zasadach, w jakiej wysokości i jakie konkretnie czynności związane z wydaniem gazety (np. druk, skład, kolportaż) są finansowane z funduszy partii ${ }^{170}$. Wniosek dotyczył także pewnych kwestii ogólnych związanych $\mathrm{z}$ funkcjonowaniem partii, a mianowicie $\mathrm{w}$ jakim dokumencie uregulowane są zasady korzystania z logo; czy członkowie partii, a także osoby fizyczne i prawne niebędące członkami partii mogą posługiwać się jej logo, a jeżeli tak, to na jakich zasadach i w jakich celach. Powracając na grunt konkretnej sprawy, wójt pytał także, czy dana partia polityczna poprzez oznakowanie przedmiotowej gazety przez radnego logiem partyjnym bierze odpowiedzialność za treść znajdujących się w niej tekstów.

169 Wyrok Trybunału Konstytucyjnego z 8 marca 2000 r., Pp 1/99, OTK ZU nr 2/A/2000, poz. 58 .

${ }^{170}$ Wyrok Wojewódzkiego Sądu Administracyjnego w Warszawie z 6 listopada 2013 r., II SAB/Wa 447/13, CBOSA. 
Jak można było przewidywać, odpowiedź partii politycznej na wniosek była negatywna, albowiem w jej przekonaniu żądane informacje nie stanowią informacji publicznej. Skarga skierowana przez wójta do sądu administracyjnego została jednak uznana za uzasadnioną ${ }^{171}$. Udział partii politycznej w życiu publicznym może być realizowany poprzez wydawanie gazet czy biuletynów informacyjnych. Co za tym idzie, zasady finansowania tego nośnika komunikacji z obywatelem, sygnowania publikatorów znakami identyfikującymi partię polityczną czy zakres odpowiedzialności za publikowane treści są nierozerwalnie związane z domeną publiczną. W opinii sądu wskazany zakres działalności odnosi się do funkcjonowania partii w sferze publicznej i przez to stanowi informację publiczną w rozumieniu art. 1 ust. 1 UDIP ${ }^{172}$.

Powyższy wyrok został jednakże uchylony przez NSA, który zarzucił sądowi niższej instancji powierzchowność w kwalifikowaniu żądanych informacji jako informacji publicznej. W szczególności NSA zasugerował, że znak graficzny odnosi się do wewnętrznej sfery działania partii, zakwestionował walor informacji publicznej w odniesieniu do spraw związanych z logo partii, jak również kwestii odpowiedzialności partii politycznej za treści publikowane $\mathrm{w}$ lokalnej gazecie ${ }^{173}$. W kontekście tej ostatniej sprawy sąd zadał pytanie, czy na podstawie UDIP możliwe jest zobowiązywanie określonego podmiotu do składania oświadczeń o określonej treści. NSA podniósł również, że niektóre żądane informacje, np. kto wydaje gazetę oraz kto ponosi odpowiedzialność za treści w niej drukowane są ogólnodostępne, gdyż wynikają z rejestru gazet - art. 20 ust. 1 Prawa prasowego ${ }^{174}$.

Kolejnym zagadnieniem rozważanym w judykaturze jest status informacji dotyczących sposobu ustalania wysokości składek członkowskich oraz dokumentów, na podstawie których składka członkowska jest ustalana. Orzecznictwo w tym zakresie nie jest jednolite.

Warszawski WSA przyjął argumentację, że sposób ustalania wysokości składek członkowskich stanowi element polityki składkowej partii, który nie należy do materii ważnej dla ogółu, nie jest sprawą publiczna,

171 Tamże.

172 Tamże.

${ }^{173}$ Wyrok Naczelnego Sądu Administracyjnego z 3 października 2014 r., I OSK 429/14, CBOSA.

${ }^{174}$ Ustawa z dnia 26 stycznia 1984 r. - Prawo prasowe (Dz. U. Nr 5, poz. 24 z późn. zm.). 
gdyż nie wpływa na funkcjonowanie ogółu ani też nie oddziałuje bezpośrednio na sprawy publiczne ${ }^{175}$. Jest to sprawa wewnętrzna partii, odnosząca się do trybu i motywów prowadzenia polityki wewnątrzpartyjnej. Zdaniem sądu nie dotyczy ona ani źródeł, ani sposobu gromadzenia środków finansowych, które to informacje są bezsprzecznie jawne i winny być ujawnione. Idąc dalej tokiem swoich rozważań WSA stwierdził, że dokumentacja dotycząca materii niestanowiącej informacji publicznej takiej informacji również nie stanowi. Dokumenty, na podstawie których składka członkowska jest ustalana stanowią jeden z elementów kształtujących politykę wewnątrzpartyjna, nie dotyczą danych publicznych i pozostają bez związku ze sprawami publicznymi ${ }^{176}$.

NSA zajął jednak stanowisko przeciwne, stwierdzając, że partia polityczna pełni funkcje publiczne, a tym samym żądane informacje spełniają warunki informacji publicznej ${ }^{177}$. Skład orzekający nie wdawał się w ogóle w odniesienia do rozbudowanej argumentacji powołanej przez sąd niższej instancji, zadowalając się wyprowadzeniem waloru informacji publicznej co do żądanych informacji z tezy o spełnianiu przez daną partię funkcji publicznych. Z kolei w odniesieniu do żądanej dokumentacji sąd uznał, że ustalanie wysokości składki członkowskiej oraz innych świadczeń członkowskich oraz tryb ich zbierania należy do kompetencji Komitetu Politycznego, który jako statutowy organ partii jest jednocześnie podmiotem publicznym ${ }^{178}$.

Analizując orzecznictwo sądów administracyjnych warto zwrócić szczególną uwagę na kwestię, która ma bardzo istotne znaczenie dla poprawnego funkcjonowania partii politycznych i wypełniania przez nie swojej ustrojowej roli, a mianowicie na odrzuconą przez sądy próbę pozyskania informacji dotyczącej spotkań partyjnych jako informacji publicznej. Jak bowiem wynika z orzecznictwa, informacje i dokumenty dotyczące spotkania liderów partii politycznych (z wyłączeniem kosztów, faktur, rachunków oraz umów) nie stanowią informacji publicznej.

W związku ze spotkaniem międzynarodowym lidera polskiej partii politycznej ze swoim zagranicznym odpowiednikiem, pewne stowarzy-

175 Wyrok Wojewódzkiego Sądu Administracyjnego w Warszawie z 26 października 2012 r., II SAB/Wa 343/12, CBOSA.

176 Tamże.

177 Wyrok Naczelnego Sądu Administracyjnego z 27 czerwca 2013 r., I OSK 513/13, CBOSA.

178 Tamże. 
szenie zwróciło się do tej partii o udostępnienie w trybie UDIP m.in. informacji, kto wystąpił z zaproszeniem na to spotkanie wraz z udostępnieniem skanów dokumentów, e-maili związanych z organizacją tego spotkania, notatek, protokołów, stenogramów, innych dokumentów zawierających informację o przebiegu tego spotkania, a także wymienienie, czego dotyczyło spotkanie, jeżeli nie zostały sporządzone wyżej wskazane dokumenty.

Oddalając skargę stowarzyszenia, warszawski sąd administracyjny przeprowadził obszerny i wnikliwy wywód, który zapewne niejeden raz zostanie w przyszłości przytoczony w orzecznictwie i rozważaniach doktrynalnych ${ }^{179}$.

Jak zauważył sąd, informacja publiczna musi dotyczyć sfery istniejących faktów i danych, nie zaś niezmaterializowanych w jakiejkolwiek postaci zamierzeń podejmowania określonych działań. Art. 11 ust. 1 Konstytucji gwarantuje wolność tworzenia i działania partii politycznych. Zarówno organizowanie spotkań przedstawicieli ciał statutowych partii (w tym także na poziomie międzynarodowym), jak również korespondencja czy dokumentacja tego rodzaju spotkań służą bieżącej pracy partii politycznej. UDIP nie jest aktem prawnym służącym do sprawowania społecznej kontroli w zakresie wewnętrznych spraw partii politycznej. Uznanie waloru informacji publicznej w odniesieniu do żądanych w niniejszym kazusie informacji prowadziłoby w konsekwencji do naruszenia zasady wolności działania partii politycznej. Wpływanie bowiem przez kogokolwiek - na skutek dysponowania pozyskanymi w trybie UDIP informacjami o pracach czy zamierzeniach partii politycznej - na kształt jej działalności prowadziłoby pośrednio do ograniczenia wolności działania tejże partii ${ }^{180}$.

Jak trafnie skonstatował skład orzekający, dostęp do informacji publicznej wynika z zasady udziału obywateli w życiu publicznym, który nie może być jednak rozumiany jako uczestniczenie $\mathrm{w}$ wewnętrznych pracach czy działaniach partii politycznej. Spotkanie, którego dotyczył wniosek służyło wewnętrznej rozmowie dwóch polityków, którzy korzystając z umocowania do kształtowania taktyki i strategii politycznej swoich ugrupowań winni mieć zapewnioną ochronę swobody swojej działalno-

179 Wyrok Wojewódzkiego Sądu Administracyjnego w Warszawie z 7 czerwca 2016 r., II SAB/Wa 113/16, CBOSA.

180 Tamże. 
ści. Przyjęcie odmiennego poglądu mogłoby prowadzić do naruszenia ustrojowej zasady wolności działania partii politycznej.

Istotnym i trafnym jest spostrzeżenie sądu, że nawet $\mathrm{w}$ przypadku podmiotów będących organami władzy publicznej czy innych podmiotów wykonujących zadania publiczne, informacje w zakresie konsultacji, uzgadniania poglądów czy stanowisk nie stanowią informacji publicznej. Powyższe nie jest bowiem wyrazem ostatecznego stanowiska organu co do sposobu załatwienia sprawy i nie przesądza o faktycznej realizacji jakiegoś zadania publicznego. Tym bardziej więc w odniesieniu do partii politycznej brak jest podstaw do przyjęcia odmiennego stanowiska ${ }^{181}$.

Na kanwie powyższego kazusu warszawski WSA sformułował także regułę o charakterze ogólnym, stanowiącą kontynuację wcześniejszego orzecznictwa. Zgodnie $\mathrm{z}$ tym poglądem uznanie informacji o metodach i środkach działania partii politycznej za informację publiczną byłoby wpływaniem państwa na działalność partii politycznej ${ }^{182}$.

Prowadziłoby to również do niczym nieusprawiedliwionego korzystania innych uczestników systemu politycznego z dorobku partii politycznej, stanowiąc zaprzeczenie pluralizmu, tzn. wolnego konkurowania idei, programów i interesów. Instytucjonalizacja partii politycznych nie może zatem prowadzić do uzyskania przez państwo wpływu na stosowane przez partie metody i środki działania ${ }^{183}$.

Tematyka powyższa posiada charakter pokrewny w stosunku do statusu dokumentów wewnętrznych w kontekście informacji publicznej. Jak słusznie zauważyła A. Sarota, problemem jest określenie, w którym momencie działalności organów władzy pojawia się na tyle skonkretyzowany i oficjalny rezultat tych działań, że może on zasługiwać na miano działalności. Ponadto, na ile nieoficjalny proces przygotowania określonych działań stanowi informację publiczną podlegającą udostępnieniu, szczególnie w kontekście uzgadniania określonych zamierzeń i decyzji politycznych pomiędzy koalicjantami politycznymi. Przedwczesne ujawnianie informacji, które nie są jeszcze oficjalnym stanowiskiem, może bowiem prowadzić do konfliktów społecznych i politycznych oraz informacyjnego chaosu ${ }^{184}$.

181 Tamże.

182 Tamże.

${ }^{183}$ Wyrok Naczelnego Sądu Administracyjnego z 26 listopada 2014 r., I OSK 633/14, CBOSA.

184 A. Sarota, Granice dostępności informacji, s. 55. 
Z kolei T.R. Aleksandrowicz zwrócił uwagę na problem tzw. przestrzeni politycznej władzy publicznej, prawa do intelektualnej swobody formułowania wstępnych rozwiązań, które nie muszą stać się podstawą rozwiązania ostatecznego, ale powinny mieć miejsce i odbywać się bez nacisku opinii publicznej ${ }^{185}$. Autor podaje przy tym przykład sytuacji, w której rząd może być zainteresowany uzyskaniem opinii eksperta w jakiejś sprawie, która może okazać się bulwersująca, kontrowersyjna. Ujawnienie takiej opinii może dać asumpt opozycji do oskarżania rządu o zamiar przyjęcia określonego rozwiązania, choć sprawa nadal jest w toku, a otrzymana opinia eksperta nie przesądza jej rozwiązania ${ }^{186}$. Trzeba zauważyć, że wszystkie zastrzeżenia formułowane w literaturze odnośnie do ujawniania wewnętrznych informacji przez organy władzy nabierają dalszej ostrości, jeśli odnieść je do partii politycznych, które przecież nie powinny podlegać równie surowemu reżimowi informacyjnemu, co organy administracji publicznej. Zgodzić się należy z poglądem, że z przyczyn technicznych i organizacyjnych nałożenie na partie polityczne ustawowego obowiązku przedstawiania pełnej dokumentacji każdemu podmiotowi nie jest rozwiązaniem właściwym ${ }^{187}$.

\section{Odmowa udostępnienia informacji}

Ostatnie z zagadnień, jakie wyodrębnić można na podstawie orzecznictwa sądów administracyjnych dotyczy charakteru odmowy udostępnienia informacji. Powołanie się na ograniczenia w dostępie do informacji publicznej w piśmie niemającym charakteru decyzji jest bezskuteczne.

W poniższym kazusie partia polityczna w odniesieniu do umów (a nie faktur) objętych wnioskiem powołała się na tajemnicę przedsiębiorcy. Twierdzenie to zostało jednak zawarte w piśmie odmownym niemającym charakteru decyzji. Jak słusznie zauważył NSA w wyroku rozpatrującym skargę kasacyjną od wyżej omówionego orzeczenia ${ }^{188}$, zaistniała sprzecz-

185 T.R. Aleksandrowicz, Komentarz do ustawy o dostępie, s. 9-10.

186 Tamże, s. 197.

187 M. Gałązka, M. Solon-Lipiński, J. Zbieranek, Przejrzystość finansowania kampanii, s. 22.

188 Wyrok Naczelnego Sądu Administracyjnego z 2 października 2014 r., I OSK 564/14, CBOSA. 
ność pomiędzy stwierdzeniem, że żądanie nie może być realizowane na podstawie przepisów UDIP a powiadomieniem o zastosowaniu przewidzianego $\mathrm{w}$ tej ustawie wyłączenia informacji publicznej spod udostępnienia. Zastosowanie tej formy odpowiedzi przez partię polityczną mogło wywoływać negatywne skutki dla wnioskodawcy poprzez wprowadzenie go w błąd i narażenie na pozbawienie możliwości ochrony praw na drodze sądowej ${ }^{189}$. Ponieważ procedura sądowoadministracyjna nie przewiduje łączenia instytucji skargi na bezczynność organu z zaskarżeniem decyzji, sąd I instancji uznał, że w sprawie doszło do bezczynności organu. Partia polityczna nie udzieliła bowiem stosownych informacji, nie wydała decyzji o odmowie udzielenia skonkretyzowanych informacji publicznych z uwagi na dobra prawnie chronione czy brak szczególnie istotnego interesu publicznego, ani też nie umorzyła postępowania ${ }^{190}$. Stanowisko to podzielił NSA.

Na gruncie UDIP można uznać za bezczynność również odmowę udzielenia informacji publicznej, dokonaną w innej formie prawnej niż przewidziana dla tej czynności. Zdaniem sądu z bezczynnością podmiotu zobowiązanego mamy do czynienia nie tylko wówczas, gdy milczy on w odniesieniu do wniosku, lecz także wtedy, gdy odmawia takiej informacji w nieprzewidzianej do tej czynności formie prawnej ${ }^{191}$. Partia polityczna w skardze kasacyjnej od tego wyroku przywołała orzeczenie z 2004 r. ${ }^{192}$ twierdząc, że w związku z brakiem legalnej definicji przyjmuje się, że $z$ bezczynnością mamy do czynienia wówczas, gdy w prawnie ustalonym terminie organ nie podjął żadnych czynności w sprawie i mimo istnienia ustawowego obowiązku nie zakończył postępowania wydaniem decyzji, postanowienia lub innego aktu albo nie podjął stosownej czynności ${ }^{193}$.

Argumentacja sądu I instancji została podtrzymana przez NSA, który w przytoczonej wyżej argumentacji powołał się na potencjalne negatywne skutki dla wnioskodawcy wynikające z braku możliwości łączenia instytucji skargi na bezczynność z zaskarżeniem decyzji. Tak więc partia zobowiązana do udzielenia informacji publicznej powinna wyrazić swoje

189 Tamże.

190 Tamże.

${ }^{191}$ Wyrok Wojewódzkiego Sądu Administracyjnego w Warszawie z 15 listopada 2013 r., II SAB/Wa 408/13, CBOSA.

${ }_{192}$ Wyrok Wojewódzkiego Sądu Administracyjnego w Lublinie z 13 października 2005 r., III SAB/Lu 15/05, CBOSA.

${ }^{193}$ Wyrok Naczelnego Sądu Administracyjnego z 2 października 2014 r., I OSK 564/14, CBOSA. 
stanowisko oddzielnie co do faktur, uznając w formie pisemnej, że nie stanowią one informacji publicznej, oddzielnie zaś co do umów, wydając decyzję odmowną z powołaniem się na tajemnicę przedsiębiorcy.

\section{Zakończenie}

Tematyka podjęta w niniejszym opracowaniu znajduje się wciąż in statu nascendi. Pozostaje w ten sposób wdzięcznym przedmiotem dla badacza, lecz zarazem gruntem grząskim i niepewnym dla przyporządkowanych jej podmiotów, konkretnie zaś partii politycznych, a także stowarzyszeń obywatelskich i innych osób, zaangażowanych w szerzenie i ugruntowywanie jawności życia publicznego. Warto więc podjąć wysiłek teoretycznego uporządkowania i wsparcia rozważań orzeczniczych, co przysłużyć się może (jak autor żywi głęboką nadzieję) praktyce stosowania UDIP.

Jak wynika z przeanalizowanego orzecznictwa, kluczowymi problemami $\mathrm{w}$ zakresie udostępniania informacji publicznej przez partie polityczne są: określenie zakresu elementu publicznego w działalności partyjnej, zapewnienie jawności finansów partii politycznych, zakreślenie granic elementu wewnętrznego, kontrola odmowy udostępniania informacji, która jest narzędziem, jakim często posługują się partie niechętne upublicznieniu informacji. Powyższe zagadnienia należy postrzegać w perspektywie dorobku nauki prawa, który, o ile w samym przedmiocie udostępniania informacji publicznej przez partie polityczne pozostaje ograniczony, o tyle obejmuje bogatą literaturę w odniesieniu do licznych pojęć, instytucji, problemów, które winny być brane pod uwagę przy analizowaniu tego przedmiotu.

Słowa kluczowe: prawo do informacji, zasada jawności, partie polityczne, dostęp do informacji, orzecznictwo, sądy administracyjne

\section{Bibliografia}

Aleksandrowicz M., Jamróz A., Jamróz J. (red.), Demokratyczne państwo prawa. Zagadnienia wybrane, Białystok 2014. 
Aleksandrowicz T.R., Komentarz do ustawy o dostępie do informacji publicznej, Banaszak B., Konstytucja Rzeczypospolitej Polskiej. Komentarz, Warszawa 2009.

Banaszak B., Bernaczyk M., Konsultacje społeczne i prawo do informacji o procesie prawotwórczym na tle Konstytucji RP oraz postulatu "otwartego rzadu”, "Zeszyty Naukowe Sądownictwa Administracyjnego" 2012, nr 4.

Bąkiewicz M., Prawo do informacji w jednostkach samorzadu terytorialnego, [w:] T. Gardocka (red.), Obywatelskie prawo do informacji, Warszawa 2008.

Bernaczyk M., Funkcja prawa do informacji w polskim porzadku prawnym, [w:] M. Jabłoński (red.), Realizacja i ochrona konstytucyjnych wolności i praw jednostki w polskim porządku prawnym, Wrocław 2014.

Bernaczyk M., Obowiazek bezwnioskowego udostępniania informacji publicznej, Warszawa 2008.

Bernaczyk M., Prawo do informacji publicznej w Polsce i na świecie, Warszawa 2014.

Bernaczyk M., Wybrane problemy udostepniania informacji publicznych w BIP $w$ świetle orzecznictwa sadów administracyjnych oraz propozycje ich przezwyciężania, informacjapubliczna.org.pl [dostęp: 11.03.2017 r.].

Bidziński M., Finansowanie partii politycznych w Polsce, Warszawa 2011.

Bidziński M., Konstytucyjne prawo dostępu do informacji publicznej, „Przegląd Prawa Konstytucyjnego" 2012, nr 4.

Bień-Kacała A., Problematyka partii politycznych w orzecznictwie Trybunału Konstytucyjnego, „Toruńskie Studia Polsko-Włoskie” 2016, t. XII.

Biernat S., Prywatyzacja zadań publicznych. Problematyka prawna, WarszawaKraków 1994.

Błaszczyńska A., Zakres podmiotowy prawa do informacji publicznej, „Przegląd Prawa Publicznego" 2010, nr 6.

Boć J. (red.), Prawo administracyjne, Wrocław 2004.

Bojar-Fijałkowski T., Dostęp do informacji publicznej - wybrane zagadnienia materialnoprawne i proceduralne z uwzględnieniem informacji o środowisku i jego ochronie jako szczególnego rodzaju informacji publicznej, [w:] A. Lusińska, A. Kalinowska-Żeleźnik (red.), Dostęp do informacji publicznej Wybrane aspekty teorii i praktyki, Gdańsk 2014.

Bułajewski S., Ossowska-Salamonowicz D., Jawność działania organów wykonawczych jednostek samorzadu terytorialnego - wybrane zagadnienia, "Journal of Modern Science" 2016, nr 4.

Cern G., Bojar-Fijałkowski T., Uprawnienia mieszkańców jednostek samorzadu terytorialnego w zakresie dostęu do informacji publicznej, „Filozofia Publiczna i Edukacja Demokratyczna" 2014, nr 1.

Chmaj M., Finansowanie partii politycznych, [w:] M. Chmaj (red.), Finansowanie polityki w Polsce na tle europejskim, Toruń 2008.

Chmaj M., Jawność finansowania polityki, [w:] M. Chmaj (red.), Finansowanie polityki w Polsce na tle europejskim, Toruń 2008. 
Chmaj M. (red.), Wolności i prawa człowieka w Konstytucji Rzeczypospolitej Polskiej, Warszawa 2008.

Chmaj M., Sokół W., Żmigrodzki M., Teoria partii politycznych, Lublin 1997.

Czarnow S., Prawo do informacji publicznej w Polsce a wymogi prawa europejskiego, "Samorząd Terytorialny” 2007, nr 4.

Czerw J., Prawo do informacji publicznej w praktyce działania urzędów administracji samorzadowej, ,Rocznik Administracji Publicznej” 2016, nr 2.

Dalka-Noga M., Biuletyn Informacji Publicznej jako forma dostepu do informacji publicznej, „Studia Iuridica Toruniensia” 2013, t. XIII.

Dolnicki B., Cybulska R., Realizacja zasady jawności i dostępu do informacji publicznej w samorządzie terytorialnym, [w:] J. Kosiński, K. Krak (red.), Korupcja i antykorupcja - wybrane zagadnienia Szczytno 2011.

Drzonek M., Wielokadencyjność bez afiliacji partyjnej? Spostrzeżenia po reelekcjach "wiecznych prezydentów" w 2014 r., „Przegląd Politologiczny" 2016, nr 1.

Dudek D., Zasady ustroju III Rzeczypospolitej Polskiej, Warszawa 2009.

Fundowicz S., Dynamiczne rozumienie zadania publicznego, [w:] J. Supernat (red.), Między tradycją a przyszłościa w nauce prawa administracyjnego. Księga jubileuszowa dedykowana Profesorowi Janowi Bociowi, Wrocław 2009.

Gałązka M., Solon-Lipiński M., Zbieranek J., Przejrzystość finansowania kampanii wyborczych i partii politycznych. Wybrane problemy i rekomendacje, Warszawa 2012.

Gąsior T., Problematyka finansowania partii politycznych w Polsce, „Przegląd Sejmowy" 2013, nr 5.

Górzyńska T., Geneza i rozwój prawa do informacji, [w:] A. Dragoń, A. Lityński, G. Sibiga (red.), Wspótczesne problemy samorządu terytorialnego - dostęp do informacji publicznej, Tychy 2004.

Górzyńska T., Prawo do informacji i zasada jawności administracyjnej. Orzecznictwo Sąu Najwyższego oraz Trybunału Konstytucyjnego, Kraków 1999.

Granat M., Policastro P., Sobczak J. (red.), Partie polityczne we współczesnym konstytucjonalizmie, Lublin 2001.

Izdebski K., Wykonywanie zadań organów administracji jako przesłanka udostępniania informacji publicznej, "Przegląd Naukowy Disputatio" 2013, t. XVI.

Jabłońska A., Udostępnienie informacji publicznej jako podstawowe prawo społeczeństwa informacyjnego, [w:] A. Lusińska, A. Kalinowska-Żeleźnik (red.), Dostęp do informacji publicznej. Wybrane aspekty teorii i praktyki, Gdańsk 2014.

Jabłoński M., "Dokument wewnętrzny" i jego udostępnienie na podstawie Konstytucji RP oraz ustawy o dostępie do informacji publicznej, [w:] M. Jabłoński, S. Jarosz-Żukowska (red.), Aktualne wyzwania ochrony wolności i praw jednostki. Prace uczniów i wspótpracowników dedykowane Profesorowi Bogusławowi Banaszakowi, Wrocław 2014.

Jabłoński M., Prawo do ponownego wykorzystania informacji publicznej - nowy etap rozwoju prawa do informacji, [w:] R. Balicki, M. Masternak-Kubiak 
(red.), W stużbie dobru wspólnemu. Księga Jubileuszowa dedykowana Profesorowi Januszowi Trzcińskiemu, Warszawa 2012.

Jabłoński M., Prawo dostępu do informacji publicznej a prawo petycji, [w:] R. Balicki, M. Jabłoński (red.), Teoretyczne i praktyczne aspekty realizacji prawa petycji, Wrocław 2015.

Jabłoński M., Realizacja prawa dostępu do informacji publicznej poprzez wglad do dokumentu, [w:] B. Banaszak, M. Jabłoński, S. Jarosz-Żukowska (red.), Prawo w stużbie państwu i społeczeństwu. Prace dedykowane Profesorowi Kazimierzowi Działosze z okazji osiemdziesiatych urodzin, Wrocław 2012.

Jabłoński M., Społeczeństwo obywatelskie a konstytucyjne prawo dostępu do informacji publicznej, [w:] E. Gdulewicz, H. Zięba-Załucka (red.), Dziesięć lat Konstytucji Rzeczypospolitej Polskiej, Rzeszów 2007.

Jabłoński M., Udostępnianie informacji publicznej w formie wgladu do dokumentu, Wrocław 2013.

Jabłoński M., Udostępnianie informacji publicznej w trybie wnioskowym, Wrocław 2009.

Jabłoński M., Wejście w życie ustawy o dostępie do informacji publicznych, „Acta Universitatis Wratislaviensis. Przegląd Prawa i Administracji” 2002.

Jabłoński M., Wygoda K., Dostęp do informacji i jego granice, „Acta Universitatis Wratislaviensis" 2002.

Jackowska A., Zbieranek J., Społeczna kontrola finansowania partii politycznych, [w:] J. Zbieranek (red.), Subwencje z budżetu państwa dla partii politycznych. Jawność $i$ kontrola, Warszawa 2008.

Jakimowicz W., Publiczne prawa podmiotowe, Kraków 2002.

Jarzęcka-Siwik E., Dostęp do informacji publicznej (uwagi krytyczne), „Kontrola Państwowa" 2002, nr 1.

Jarzęcka-Siwik E., Jawność warunkiem skutecznego i etycznego działania administracji, „Kontrola Państwowa” 2005, nr 1.

Jaśkowska M., Dostęp do informacji publicznej - zagadnienia wybrane, materiał na Konferencję sędziów NSA, Popowo 14-16 października 2002 r., Warszawa 2002.

Jaśkowska M., Dostęp do informacji publicznych w świetle orzecznictwa Naczelnego Sadu Administracyjnego, Toruń 2002.

Jaśkowska M., Jakość i spójność rozwiazań prawnych w świetle nowelizacji ustawy o dostępie do informacji publicznej, [w:] D.R. Kijowski, P.J. Suwaj (red.), Kryzys prawa administracyjnego?, t. 1, Warszawa 2012.

Juchniewicz J., O potrzebie nowych rozwiazań w zakresie finansowania partii politycznych uwag kilka, „Studia Prawnoustrojowe” 2012, nr 18.

Kamińska I., Rozbicka-Ostrowska M., Ustawa o dostępie do informacji publicznej. Komentarz praktyczny, Warszawa 2008.

Koniuszewska E., Srodki ograniczające nadużycia władzy $w$ jednostkach samorzadu terytorialnego w ustrojowym prawie administracyjnym, Warszawa 2009.

Kosowska-Gąstoł B., Prawna instytucjonalizacja partii politycznych na poziomie europejskim, „Studia Europejskie” 2005, nr 3. 
Majchrowski J., Partie polityczne w Polsce współczesnej: między konstytucyjnym ideałem a ustawowa rzeczywistościa, "Studia Iuridica” 2013, t. 56.

Majchrowski J., Partie polityczne w świetle nowej Konstytucji, „Państwo i Prawo” 1997, nr 11-12.

Nitecki S., Udział podmiotów niepublicznych w realizacji zadań pomocy społecznej, „Roczniki Administracji i Prawa” 2012, t. XII.

Olejniczak-Szałkowska E., Zasada jawności administracyjnej, [w:] M. Stahl (red.), Prawo administracyjne. Pojeccia, instytucje, zasady w teorii i orzecznictwie, Warszawa 2013.

Pietras S.M., Szustakiewicz P., Podmioty zobowiazane do udzielenia informacji publicznej w rozumieniu art. 4 ustawy z dnia 6 września 2001 r. o dostępie do informacji publicznej, „Ius Novum” 2001, nr 4.

Piotrowski R., Demokracja a finansowanie partii politycznych w świetle Konstytucji $R P$, „Studia Iuridica Lublinensia” 2014, nr 22.

Piskorz-Ryń A., Dostęp do informacji publicznej - zasady konstrukcyjne ustawy, „Kwartalnik Prawa Publicznego" 2002, nr 4.

Piskorz-Ryń A., Jawność działania administracji publicznej, [w:] H. Machińska (red.), Prawo do dobrej administracji, Warszawa 2003.

Sarota A., Granice dostępności informacji publicznej, „Kontrola Państwowa” 2012, nr 6.

Sibiga G. (red.), Główne problemy prawa do informacji w świetle prawa $i$ standardów międzynarodowych, europejskich $i$ wybranych państw Unii Europejskiej, Warszawa 2013.

Sierpowska I., Pomoc społeczna jako administracja świadcząca. Studium administracyjnoprawne, Warszawa 2012.

Sitniewski P., Bezpłatność czy bezkosztowość udostepniania informacji publicznej?, [w:] E. Ura (red.), Sprawność działania administracji samorzadowej, Rzeszów 2006.

Sitniewski P., Ustawa o dostepie do informacji publicznej. Komentarz, Wrocław 2011.

Skotnicki K., Finansowanie partii politycznych w Polsce, „Toruńskie Studia Polsko-Włoskie" 2016, t. XII.

Skotnicki K., Modele i źródła finansowania partii politycznych, „Przegląd Sejmowy" 2014, nr 1.

Skrzydło W., Konstytucja Rzeczypospolitej Polskiej. Komentarz, Kraków 2000.

Sobczak J., Konstytucyjna wolność tworzenia partii politycznych w Polsce, [w:] M. Granat, P. Policastro, J. Sobczak (red.), Partie polityczne we współczesnym konstytucjonalizmie, Lublin 2001.

Stahl M., Cele publiczne i zadania publiczne, [w:] J. Zimmermann (red.), Koncepcja systemu prawa administracyjnego, Warszawa 2007.

Stasikowski R., O pojęciu zadań publicznych (studium z zakresu nauki administracji i nauki prawa administracyjnego), "Samorząd Terytorialny” 2009, nr 7-8. 
Szustakiewicz P., Dostęp do informacji na podstawie ustawy o dostepie do informacji publicznej, [w:] T. Gardocka (red.), Obywatelskie prawo do informacji, Warszawa 2008.

Tabernacka M., Zakres wykonywania zadań publicznych przez organy samorzadów zawodowych, Wrocław 2007.

Tarnacka K., Prawo do informacji w Polsce, „Państwo i Prawo” 2003, nr 5.

Tarnacka K., Prawo do informacji w polskim prawie konstytucyjnym, Warszawa 2009.

Tomaszewska K., Realizacja jawności orzeczeń sądowych w trybie dostępu do informacji publicznej jako element społecznej kontroli, „Przegląd Prawa Konstytucyjnego" 2015, nr 3.

Tusiński P.A., Zasady ogólne materialnego prawa administracyjnego, [w:] M. Zdyb, J. Stelmasiak (red.), Prawo administracyjne, Warszawa 2016.

Uliasz J., Finansowanie prezydenckiej kampanii wyborczej w 2010 r., [w:] S.J. Jaworski, K.W. Czaplicki (red.), Księga Pamiątkowa z okazji obchodów 20-lecia demokratycznych wyborów w Polsce, Warszawa 2011.

Uziębło P., Aspekty ustrojowe stosunków wewnątrzpartyjnych, „Toruńskie Studia Polsko-Włoskie" 2016, t. XII.

Wiszniowski R., Marketing wyborczy. Studium kampanii wyborczych w systemach prezydenckich i semiprezydenckich (Finlandia, Francja, Polska, Stany Zjednoczone), Warszawa-Wrocław 2000.

Wojtas K., Finansowanie partii politycznych w Polsce w latach 2002-2006, "Athenaeum" 2008, nr 19.

Wojtyczek K., Konstytucyjny status jednostki w państwie polskim, [w:] P. Sarnecki (red.), Prawo konstytucyjne RP, Warszawa 2008.

Zacharko L., Prywatyzacja zadań publicznych gminy. Studium administracyjno-prawne, Katowice 2000.

Zaleśny J., Finansowanie kampanii wyborczej w wyborach parlamentarnych. Regulacje prawne $i$ ich stosowanie, "Ius Novum” 2011, nr 4.

Zaleśny J., Finansowanie parlamentarnej kampanii wyborczej - specyfika polska, [w:] E. Pietrzyk-Zieniewicz (red.), Przed wyborami. Konflikty, strategie, nadzieje, "Studia Politologiczne” 2005, nr 9.

Zdunek A., Ograniczenie prawa do informacji publicznej w orzecznictwie sadów administracyjnych - wybrane zagadnienia, "Rocznik Administracji Publicznej” 2016, nr 2.

\section{ACT ON ACCESS TO PUBLIC INFORMATION AND TRANSPARENCY OF POLITICAL PARTIES IN POLAND}

\section{$\mathrm{S} \mathbf{u} \mathbf{m} \mathbf{m}$ a $\mathbf{r} \mathbf{y}$}

The Constitution of the Republic of Poland and Act of 6 September 2001 on access to public information ensures the right to information about the ac- 
tivities of public authority organs as well as subjects performing public tasks. Political parties are obligated by the Act to provide information about their funding. Furthermore, according to the Supreme Administrative Court of Poland there is no doubt that a political party fulfils a public role (case no. I OSK $513 / 13$ ), which results in an obligation to disclose information on their activity and finances to the public. The case law of administrative courts brings many additional rules: the definition of an official document of the Code of Civil Procedure does not apply under the Act; the sphere of public information contains all kinds of data on party finances, including paid invoices and contracts of civil law, as well as information and documents about how to determine the amount of membership fees. Parties are also obligated to disclose resolutions of the Management Board and other documents produced by the party organs, unless these documents are of a general organizational nature and they do not provide any additional information. Political parties do not however, have such obligation regarding information and documents relating to the meetings of their leaders, as well as other information on the methods and means of action of the party.

Keywords: right to information, transparency, political parties, access to information, case law, administrative courts

\section{ПРЕДОСТАВЯЕНИЯ ДОСТУПА К ПУБЛИЧНОЙ ИНФОРМАЦИИ ПУТЕМ ПОЛИТИЧЕСКИЕ ПАРТИИ}

\section{P е 3 г м е}

Конституция Подьской Республики и Закон о доступе к публичной информации с 6 сентября 2001 г. гарантируют право доступа к информации, которые касаются деятельности органов публичной власти и субъектов, выполняющих публичные задания. Политические партии обязаны законом к открытию для доступа информации, которые касаются их финансирования. Больше того, как постановия Главный Административный Суд, не имеет сомнения, что каждая политическая партия выполняет публичные функции (OSK 513/13). Результатом этой должности является обязательство партий к открытию для доступа информации, которые касаются их активности и финансов. Судопроизводство дополняет законные регулирования дополнительных правил, а именно понятия служебного документа из Кодекса Гражданского Поведения не имеет применения на почве обсуждаемого закона; сфера публичной информации охватывает всякого рода данные, которые касаются израсходования партией финансовых средств, в том оплаченных нее счетов и заключенных гражданско-правовых договоров, также как информация, которые касаются способа установления размера членских взносов и документов, на основании которых этот взнос устанавдивается. Также партии обязаны демонстрировать постановлении правления и другие доку- 
менты, созданные партийной структурой, разве что они имеют общий характер и не содержат ни одной дополнительной информации. В тоже время, не имеют такого статуса информация и документы, которые касаются встречи лидеров политических партий, также как другие информации о методах и средствах действия данной партии.

Ключевые слова: публичная информация, принцип открытости, политические партии, финансирование партийной деятельности, доступ к информации 